\title{
Tilregnelighet og utilregnelighet: begreper og regler ${ }^{1}$
}

\author{
Linda Gröning ${ }^{2}$
}

\begin{abstract}
As in many other countries, the Norwegian criminal law requires sanity at the time of the offense as a condition for criminal responsibility. In the legal discourse, sanity is conceived as a capability for guilt - "skyldevne" - which amounts to capacity for criminal responsibility or criminal capacity.

Yet the rules of the criminal law do not define or even mention sanity. They do, however, provide criteria for the conditions that negate sanity, thus implying insanity. According to Section 44 of the Norwegian Criminal Code, a person who was psychotic, unconscious or highly mentally retarded at the time of the offense cannot be held liable for a penalty.

The current article focuses on mental disorder as a condition for excuse. The ambition of the article is to explain the meaning and justifications of sanity as a condition for criminal responsibility. More specifically, it aims to create a clarification of the concepts of sanity and insanity as they are constructed in the criminal law and its doctrines on responsibility. As the title suggests, the article also focuses on the relation between concepts and rules. After clarifying the meaning of legal insanity, the article discusses the content of the current regulation in the criminal code and possible alternatives to it. ${ }^{*}$
\end{abstract}

\section{Innledning}

I norsk strafferett er, som i de fleste rettstaters strafferett, gjerningspersonens tilregnelighet i gjerningsøyeblikket et vilkår for straffansvar. Tilregnelighet forstås ofte som «skyldevne», som kan anses å bety strafferettslig ansvarskapasitet. ${ }^{3}$ Var gjerningspersonen på gjerningstidspunktet uten ansvarskapasitet, og altså utilregnelig, skal han eller hun frifinnes for straffansvar - men andre reaksjoner enn straff kan på visse vilkår idømmes. ${ }^{4}$

Straffeloven definerer ikke tilregnelighet positivt. I stedet angis kriterier for de omstendigheter og tilstander som innebærer utilregnelighet. Etter gjeldende straf-

* Title in English: Sanity and Insanity: Concepts and Rules. 
felov er den som er bevisstløs, psykotisk, høygradig utviklingshemmet eller under 15 år på gjerningstidspunktet utilregnelig. ${ }^{5}$

Strafferettens tilregnelighetsvilkår har blitt inngående diskutert i strafferettsvitenskapen, og også i mange andre disipliner. I samtidig norsk strafferettsvitenskap har fokuset vært på å begrunne og klargjøre de utilregnelighetstilstander som straffeloven angir. I mindre grad har diskusjonen handlet om å gi en nærmere forklaring av strafferettens underliggende begrep om tilregnelighet.

Ambisjonen med denne artikkelen er å diskutere begrunnelsene for og betydningen av strafferettens tilregnelighetsvilkår. Spørsmålene om hvordan strafferettens begreper om tilregnelighet og utilregnelighet skal forstås er diskusjonens kjerne. Som tittelen antyder fokuserer artikkelen også på relasjonen mellom begrep (i betydningen idé eller forestilling) og regelutforming. Én sak er nemlig hvordan tilregnelighet og utilregnelighet skal forstås som strafferettslige begreper. En annen sak er hvordan disse begrepene skal omsettes til rettslig forsvarlige og praktisk anvendelige utilregnelighetsregler.

De spørsmål som behandles i artikkelen kopler til mange ulike og omfattende diskusjoner innen flere ulike disipliner, som rettsteori, filosofi, teologi, psykologi og medisin. Artikkelen innrettes mot psykisk lidelse som utilregnelighetstilstand. Ambisjonsnivået begrenses i dette felt til en problemoversikt - og da primært fra et strafferettsteoretisk perspektiv. Samtidig er det vanskelig å gi en slik oversikt uten også å gi i hvert fall tentative svar på de ulike problemdimensjonene. Målsetningen er også til slutt å bidra til en nærmere forståelse av strafferettens tilregnelighetsvilkår.

\section{Begrunnelsen for et vilkår om tilregnelighet}

\subsection{De ulike forklaringsmodellene}

Utgangspunktet i det videre er at vi skal ha et tilregnelighetsvilkår og diskusjonen omfatter ikke alternativet å avskaffe det. Dette utgangspunktet er forankret i norsk rett og bør også være det. ${ }^{6}$ Videre forutsettes det at tilregnelighetsvilkåret er et ansvarsvilkår. ${ }^{7}$ Vilkåret er en del av strafferettens ansvarslære som angir de vilkår som må være oppfylt for at en person skal kunne holdes ansvarlig og straffes.

Tanken om at visse individer ikke skal holdes ansvarlige og straffes for sine handlinger har røtter langt tilbake $\mathrm{i}$ humanistisk, romersk og jødisk-kristen tradisjon. ${ }^{8}$ Strafferettens tilregnelighetsvilkår kan her anses å hvile på en betraktning om det urettferdige eller urimelige i å straffe visse personer, slik som barn eller psykisk syke. ${ }^{9}$ Slik kan tilregnelighetsvilkåret generelt begrunnes i argumentet 
om at det finnes visse moralske grenser for den offentlige maktens bruk av straff..$^{10}$

Det finnes imidlertid mange ulike posisjoner i diskusjonen om tilregnelighet, som gir ulike nærmere begrunnelser for et tilregnelighetsvilkår og dets innhold. I grove trekk kan diskusjonen i norsk rett struktureres i argumenter om skyld, argumenter om kriminalitetsforebyggelse, samt barmhjertighets- eller humanitetshensyn relatert til straffens skadepotensial. ${ }^{11}$

Argumenter om skyld bygger på en premiss om at ansvar forutsetter at en person kan klandres som skyldig for sin handling. Fra dette perspektivet avgrenser tilregnelighetsvilkåret hvem som kan straffes gjennom å framheve visse (mentale) egenskaper hos en gjerningsperson som forutsetninger for ansvarskapasitet slik som visse krav på «et minstemål av modenhet, sjelelig sunnhet og bevissthet». ${ }^{12}$ Når en gjerningsperson på handlingstiden savner slike egenskaper finnes det ikke grunnlag for å ansvarliggjøre vedkommende. En slik gjerningsperson kan ikke (forventes å) ha handlet annerledes, eksempelvis fordi han eller hun ikke kunne forstå eller vurdere sin egen handling, og kan således heller ikke klandres. Slik kan for eksempel tilfellet være med mindre barn eller psykotiske personer. I den skyldbaserte forklaringsmodellen finnes begrunnelsen for strafferettens tilregnelighetsvilkår til sist i argumentet om det feilaktige i å straffe den som er uten skyld og derfor ikke fortjener straff. ${ }^{13}$ Denne forklaringsmodellen må anses primær i norsk strafferett, noe som også fremgår av at tilregnelighet forstås som «skyldevne». ${ }^{14}$

I norsk rett er det vanlig også å gi plass for argumenter om kriminalitetsforebyggelse som en del av begrunnelsen for strafferettens tilregnelighetsvilkår, ofte mot bakgrunn av at slike argumenter er sentrale i de mer generelle begrunnelsene for statens bruk av straff. ${ }^{15}$ Argumenter om kriminalitetsforebyggelse handler tradisjonelt om allmennprevensjon eller om individualprevensjon. ${ }^{16}$ Det typiske allmennpreventive argumentet er at visse personer, slik som psykisk syke, bør gå fri fra straff ettersom straffetrusselen ikke kan ha noen normskapende og/eller handlingsdirigerende effekt på dem. ${ }^{17}$ Argumentet kan forstås ut fra standpunktet at allmennprevensjon primært relateres til straffelovgivningen: en straff idømmes for å gi troverdighet - og preventiv effekt - til lovgivningens trussel om straff. Fra denne synsvinkelen kan straffen således ikke fylle noen funksjon i relasjon til de personkategorier som på grunn av visse mentale avvik mangler evne til i det hele tatt å respondere på en straffetrussel.

Også det individualpreventive argumentet bygger oftest på en presumsjon om at straff ikke kan oppfylle sitt formål i relasjon til visse personkategorier, ettersom disse ikke kan respondere (normalt) på straff. Straffens avskrekkende og for- 
bedrende virkninger anses ikke å kunne oppnås i relasjon til disse. Når det individualpreventive argumentet fremheves i tilregnelighetskonteksten er det ofte i form av et «behandlingsargument». Det typiske argumentet er at (fengsels-)straff ikke er den riktige behandlingen av psykisk syke, ettersom det ikke får tilsiktet virkning. ${ }^{18}$ Det motsatte har imidlertid også blitt hevdet; at straff og ansvarstilskrivelse er viktig fra et behandlingsperspektiv. ${ }^{19}$

Det individualpreventive argumentet har visse koplinger til argumenter om barmhjertighet- eller humanitet. Slike argumenter bygger på at det er urimelig å holde visse personer ansvarlige og straffe dem på grunn av den belastning som straffeprosessen og fremfor alt straffen innebærer. ${ }^{20}$ I likhet med det individualpreventive argumentet, peker barmhjertighets- og humanitetsargumenter således på at straffens konsekvenser for individet kan være relevante for å begrunne tilregnelighetsvilkåret. Påstanden er imidlertid ikke her, som ved det preventive argumentet, at straffen ikke er virkningsfull. Det er den lidelse som følger av straffen som anses problematisk. Argumenter om barmhjertighets- eller humanitetshensyn fremheves i samtidig norsk strafferett særlig i relasjon til reglene om kriminell lavalder. ${ }^{21}$ Argumentene er også synlige i den allmenne diskusjonen om straffansvar for psykisk syke.

\subsection{Argumentet om skyld som hovedbegrunnelse}

En begrunnelse for tilregnelighet som et ansvarsvilkår må ikke bare kunne forklare hvorfor en person ikke skal idømmes straff. Begrunnelsen må også kunne forklare hvorfor vedkommende skal være ansvarsfri.

I dette perspektivet tilbyr bare skyldhensyn en selvstendig forklaringsmodell for strafferettens tilregnelighetsvilkår. Verken argumenter om prevensjon eller humanitets- og barmhjertighetsargumenter kan nemlig helt forklare den premissen om ansvarsfrihet som tilregnelighetsvilkåret bygger på, men forklarer bare straffrihet. Preventive argumenter om at det ikke er formålstjenlig å straffe visse personer kan like gjerne legges til grunn for regler om straffbortfall på reaksjonseller straffutmålingssiden, slik som i svensk strafferett. ${ }^{22}$ På samme måte kan humanitets- og barmhjertighetsargumenter like gjerne legges til grunn for andre konstruksjoner enn et tilregnelighetsvilkår. I strafferettssystemets struktur lokaliseres også disse argumentene fremfor alt i straffutmåling og reaksjonsvalg, og på straffegjennomføringsnivå gjennom eksempelvis krav på pleie og behandling $\mathrm{i}$ fengsler. De berører ikke slik som tilregnelighetsvilkåret spørsmålet om straffansvaret som sådant.

Argumentene om manglende preventive virkninger som tradisjonelt er brukt for å frita visse grupper fra straff bygger dessuten på empiriske antagelser som er 
svakt underbygde. I utgangspunktet er det vanskelig å si noe om hvordan straff virker på ulike individer. ${ }^{23}$ Det er vanskelig å si noe presist om straffens eventuelle kriminalitetsforebyggende virkning. Det kan reises særskilte innvendinger mot det allmennpreventive argumentet: selv om straffetrusselen ikke har noen effekt på visse psykisk syke personer kan det ikke utelukkes at det å straffe disse personene, i hvert fall i visse tilfeller av grove forbrytelser, totalt sett bidrar til å redusere samfunnets kriminalitet. ${ }^{24}$ Psykisk syke er ikke heller den eneste gruppen lovbrytere hvor straffens tilsiktede virkninger kan tenkes å utebli. Gitt mangelen av empiriske holdepunkter, kan således argumentene om straffens preventive formål like gjerne tale imot at psykisk syke fritas fra ansvar som for det. ${ }^{25}$ En annen sak, er at individers evne til på en normal måte å forholde seg til straffetrusler kan koples til strafferettens ansvarspremisser. I den utstrekning en gjerningsperson ikke har evne til å respondere på straffetrusler kan det hevdes at betingelser for ansvarskapasitet er fraværende. ${ }^{26}$

Argumentene om prevensjon og barmhjertighet og humanitet kan således ikke betraktes som selvstendige begrunnelser for strafferettens tilregnelighetsvilkår. Dette utelukker likevel ikke at argumentene, ved siden av skyldhensyn, kan ha relevans i en diskusjon om utformingen av strafferettens utilregnelighetsregler. Vi skal se videre på argumentenes betydning i regelutformingen i punkt 9 og 10. Før vi går inn i dette spørsmålet må vi imidlertid ha en klarere oppfatning av hva som ligger i strafferettens tilregnelighetsvilkår. For å forklare vilkårets innhold skal vi nå gå dypere inn i strafferettens og ansvarslærens premisser om skyld.

\section{Tilregnelighetsvilkåret i ansvarslærens systematikk}

\subsection{Skyldprinsippet som utgangspunkt}

Tilregnelighetsvilkårets begrunnelse - skyldargumentet - gjennomsyrer naturlig nok også strafferetten forøvrig. Norsk strafferett er handlings- og skyldfokusert: bare den som gjennom sin handling har brutt straffeloven kan straffes og bare dersom han eller hun kan klandres som skyldig for lovbruddet. ${ }^{27}$ Denne modellen representerer strafferettens klassiske utgangspunkt og har fătt gjennomslag i de fleste rettsstater. Den kan forklares med utgangspunkt i skyldprinsippet, som angir at straffansvar og straff bare kan komme på tale for den som kunne og burde ha handlet annerledes - og derfor kan klandres.

Skyldprinsippet har betydning for flere forhold i strafferettssystemet: på lovgivningsnivå ved å betone handlingers klanderverdighet som et kriminaliseringsargument, på domstolsnivå gjennom krav om proporsjonalitet mellom klanderverdighet og straff (slik at alvorligere og mer klanderverdige lovbrudd straffes strengere enn mindre alvorlige lovbrudd), og på straffegjennomføringsnivå gjen- 
nom regler om soningsform og soningsprogresjon. Prinsippet kommer dessuten mer overordnet til uttrykk i det prinsipielle skillet mellom straff som begrunnes med at gjerningspersonen er skyldig for det han eller hun har gjort, og strafferettslige særreaksjoner som begrunnes i samfunnsvern. ${ }^{28}$

Skyldprinsippet er i særlig grad styrende for ansvarslæren og dens vilkår for ansvar og straff. Prinsippets gjennomslag i ansvarslæren er særlig tydelig i de vilkår som berører gjerningspersonens mentale status og innstilling til sin handling, det vil si vilkårene om forsett/uaktsomhet og tilregnelighet - som vi nå skal se videre på.

\subsection{Utilregnelighet som unnskyldningsgrunn}

I norsk rettstradisjon har det vært vanlig å fremheve fire overordnede ansvarsvilkår. ${ }^{29}$ I forarbeidene til den nye straffeloven angis disse slik: «[h]andlingen må bryte loven (1), det må ikke foreligge noen straffrihetsgrunn (2), gjerningspersonen må være tilregnelig (3) og ha utvist skyld (forsett eller uaktsomhet) (4)». ${ }^{30}$ Det foregår en diskusjon om holdbarheten og hensiktsmessigheten av denne systematikken. ${ }^{31}$ Det er imidlertid enighet om at tilregnelighet er et grunnleggende vilkår for straffansvar - og at utilregnelighet medfører ansvarsfrihet.

Utilregnelighet beskrives da best som en unnskyldningsgrunn. Det betyr at gjerningspersonen ikke kan klandres, og derfor ikke er straffansvarlig, selv om handlingen ikke kan forsvares som rettmessig (slik som er tilfellet ved for eksempel nødverge). ${ }^{32}$ Gjerningspersonen unnskyldes, med andre ord, selv om det han eller hun har gjort er galt - urettmessig. Gjennom skyldprinsippet har tilregnelighetsvilkåret her en nær kopling til allmennmoralen og tanken om at «det var ikke hennes feil, hun kunne ikke for det».

Med skyldprinsippet som utgangspunkt kan gjerningspersonen kun unnskyldes når han eller hun ikke er å bebreide for å ha forårsaket sin egen utilregnelighet. Det er den ikke-klanderverdige utilregneligheten som er unnskyldende, for eksempel utilregnelighet forårsaket av psykisk lidelse. Gjeldende straffelov har regler om ansvar ved selvforskyldt rus, som imidlertid ikke fullt ut avpeiler denne tankegangen. ${ }^{33}$

\subsection{Grensedragningen mot forsettskravet}

Forklaringen av tilregnelighet som «skyldevne» skaper en viss uklarhet i relasjon til vilkåret om «skyld» i den konvensjonelle firedelingen av ansvarsvilkårene. I inndelingen sidestilles vilkåret om tilregnelighet med vilkårene om skyld; forsett og uaktsomhet. Samtidig refererer tilregnelighet, på samme måte som kravene om forsett og uaktsomhet, til mentale aspekter hos gjerningspersonen. 
Grensedragningen mellom vilkårene forstås best i relasjon til skyldprinsippet. Gjerningspersonens straffansvar følger av forventningene om adferd som straffebudene uttrykker og hvordan gjerningspersonen nærmere har forholdt seg til disse da han eller hun brøt straffebudet. Skyldprinsippet peker her blant annet på en sammenheng mellom visse mentale komponenter som forestillinger og vilje hos gjerningspersonen og dennes ansvar for sine handlinger.

Ved å utpeke visse mentale komponenter får skyldprinsippet betydning særlig på to måter. Som et grunnleggende vilkår for i det hele tatt å kunne karakterisere en handling som rettsstridig, fordrer skyldprinsippet at gjerningspersonen i en viss forstand har ment eller har kunnet forutse handlingen, slik at det inntrufne ikke bare er et rent uhell. Dette vilkåret blir ivaretatt gjennom ansvarslærens mer konkrete krav om forsett og uaktsomhet.

Forsettskravet forutsetter at gjerningspersonen oppfattet handlingens faktiske omstendigheter og i denne forstand var klar over hva han eller hun gjorde, og er det mest interessante i relasjon til kravet om tilregnelighet. Kravet relaterer seg til de vilkår i et gitt straffebud som beskriver en straffbar handling (objektivt). Dersom en person som dreper et menneske ikke er klar over at det er et menneske som blir drept, savnes forsett i relasjon til straffebudet om drap (av menneske). Men i et slikt tilfelle kan det tenkes at heller ikke kravet om tilregnelighet er oppfylt - for eksempel om gjerningspersonen på grunn av en hallusinatorisk tilstand er overbevist om at den som berøves livet er et romvesen. Her finnes således en mulig overlapping mellom kravene.

Selv om manglende tilregnelighet kan medføre manglende forsett er ikke tilregnelighetskravet, i motsetning til forsettsvilkåret, innrettet på gjerningspersonens bevissthet, innsikt eller forståelse om de faktiske omstendighetene i en handling. Kravet om tilregnelighet omhandler i stedet, som vi har sett, gjerningspersonens strafferettslige ansvarskapasitet som sådan. ${ }^{34}$ Denne ansvarskapasiteten består i den enkeltes evne til å kunne forstå, vurdere og til sist styre sine handlinger i en gitt handlingssituasjon. ${ }^{35}$

Utilregnelighet innebærer ikke nødvendigvis at en gjerningsperson ikke er klar over en handlings faktiske omstendigheter. En utilregnelig gjerningsperson kan være fullstendig klar over at han eller hun dreper et menneske, og dette kan også være hans eller hennes uttalte hensikt. Men dersom gjerningspersonen har psykotiske vrangforestillinger, og er overbevist om at drapet vil redde jorden fra en ellers sikker undergang, svikter begrunnelsene for straffansvar. Det som fritar fra ansvar i en slik situasjon er da ikke manglende forsett men at gjerningspersonen på handlingstidspunktet ikke hadde kapasitet til å forstå og vurdere (å avstå fra) handlingen. 
Til tross for at det språklig virker besynderlig å si at en person som mangler skyldevne likevel kan oppfylle vilkåret om skyld, er det altså strafferettens utgangspunkt at den utilregnelige kan oppfylle kravet om forsett. ${ }^{36}$ Det er bare i de tilfeller der forsett foreligger at tilregnelighetskravet får selvstendig betydning for ansvaret. Rent systematisk er det også grunn til å betrakte forsettskravet som primært, ettersom det, der det forutsettes for straffansvar, er nødvendig for i det hele tatt å anse en handling som rettsstridig. Utilregnelighet som en unnskyldningsgrunn kommer først på tale når det kan konstateres at det foreligger en rettsstridig handling. ${ }^{37}$

\subsection{Nedsatt tilregnelighet?}

For tilregnelighetsspørsmålet er det vanskelig å dra en skarp grense mellom ulike tilstander. Mentale avvikstilstander inntreffer med ulik styrke og symptombelastning på den enkelte. ${ }^{38}$ Slik sett kan man tale om ulike grader av tilregnelighet noe som også åpner for at en gjerningsperson kan anses å ha «nedsatt tilregnelighet» uten å være (helt) utilregnelig. Ansvarsfrihet krever imidlertid en «fullstendig utilregnelighet». Det betyr at en gjerningsperson i handlingsøyeblikket (helt) må mangle strafferettslig ansvarskapasitet. ${ }^{39}$ Kun da kan det anses rimelig å unnskylde vedkommende.

Denne snevre avgrensningen av de utilregnelige er, som vi snart skal se nærmere på, også begrunnet i de forutsetninger som ligger til grunn for det strafferettslige begrepet om utilregnelighet. En utilregnelig person mangler nemlig fra ansvarslærens perspektiv frihet og fornuftskapasitet. Likevel må man med skyldprinsippet som utgangspunkt kunne si at gjerningspersonens nedsatte tilregnelighet gjør lovbruddet mindre klanderverdig. Denne nedsatte klanderverdigheten tas det også hensyn til på straffutmålingsstadiet, gjennom at straffen settes ned eller i ytterlighetstilfellene helt faller bort. ${ }^{40}$

\section{Tilregnelighetsbegrepets nærmere innhold}

\subsection{Kjernen i tilregnelighetsbegrepet: frihet og fornuftskapasitet}

Strafferetten utmerker seg i relasjon til mange andre regelsystem gjennom å ha en særlig samfunnsetisk og moralsk karakter. De handlinger som defineres som forbrytelser anses vanligvis å være umoralske eller i hvert fall etisk problematiske handlinger som av den grunn fortjener klander og straff. ${ }^{41}$ Gjennom ansvarslærens prinsipper om klander og skyld forutsetter det strafferettslige ansvaret til sist den enkeltes moralske ansvar for sin handling. ${ }^{42}$

Tilregnelighetens moralske dimensjon ligger i den enkeltes evne til å forstå og respektere de begrunnelsene og forutsetningene som straffereglene bygger på, og 
til sist å legge dem til grunn for sine handlinger. Tilregnelighet handler slik sett om den enkeltes evne til å ta ansvar for å handle riktig og i tråd med de normer straffeloven kommuniserer. Strafferetten forutsetter at straffmyndige mennesker har en slik kapasitet og at de av den grunn kan holdes ansvarlige for sine handlinger.

Strafferettens forutsetning om ansvarskapasitet bygger på en del ulike antakelser som til slutt bunner i metafysiske premisser om at mennesker har evne til frihet og fornuft i tanke og handling - og dermed også evne til å ta ansvar for sine handlinger. Premissene om individets frihet og fornuftskapasitet utgjør kjernen i strafferettens (gjernings)personbegrep og blir tydelige gjennom tilregnelighetsvilkåret. ${ }^{43}$ De gjenspeiles også i utilregnelighetsreglene i mange rettstradisjoner ved at det avgjørende er om gjerningspersonen hadde evner til å forstå og kontrollere sine handlinger. ${ }^{44}$

Premissene om frihet og fornuft er nært sammenkoplet i strafferettens begrep om tilregnelighet. Tilregnelighet forutsetter frihet i den grunnleggende betydningen at den enkelte har kroppskontroll og kan handle i samsvar med sine intensjoner. En tilregnelig gjerningsperson må kunne forstås som en ansvarlig agent som har handlet frivillig. I den utstrekning et individ har mentale avvik som leder til manglende handlingskontroll, må denne forstås som utilregnelig. Som vi skal komme tilbake til er slike kontrollmangler likevel en noe diskutabel utilregnelighetsgrunn i strafferetten.

Frihetspremissen om den enkeltes evne til viljestyrt handling er imidlertid ikke spesifikk for tilregnelighetsbegrepet, men er en generell forutsetning for strafferettens handlingsbegrep som hele ansvarslæren baseres på. Frihet må også ses i sammenheng med fornuftsevnen. Fornuftspremissen utgjør slik sett kjernen i tilregnelighetsbegrepet. For å anses tilregnelig er det å kunne styre sine handlinger i samsvar med sine intensjoner ikke tilstrekkelig. Det kreves som vi har sett dessuten en evne til å kunne vurdere riktigheten i disse, som grunnlag for handling. Tilregnelighet særpreges således til sist fremfor alt av den enkeltes fornuftskapasitet i spørsmålet om å kunne forstå og vurdere sine handlinger i en gitt handlingssituasjon. ${ }^{45}$ Fra dette utgangspunktet skal vi nå se videre på hvilke mentale forutsetninger som tilregnelighet kan anses å forutsette.

\subsection{Mentale forutsetninger for tilregnelighet}

Frihet og fornuft er abstrakte og komplekse begreper hvis mer presise innhold må avklares gjennom teoretiske resonnementer. Samtidig er frihet og fornuft størrelser vi hele tiden forholder oss til i vårt daglige samliv og i diskusjoner med andre mennesker. 
Tilregnelighetsbegrepets premisser om frihet og fornuft kan til en viss grad også konkretiseres gjennom de evner som kan anses å utgjøre fenomenenes biologiske/psykologiske forutsetninger. En slik konkretisering av metafysiske utgangspunkter er grunnleggende for strafferetten. Strafferettens begrep om handlefrihet konkretiseres for eksempel i krav om at en gjerningsperson ikke kan holdes ansvarlig for refleksbevegelser eller spasmer. Som vi skal se er en viss konkretisering av tilregnelighetsbegrepet nødvendig for å kunne peke på de mangler hos den enkelte som skal anses som «utilregnelighetsmangler».

Som utgangspunkt for en slik konkretisering er det grunn til å fremheve visse overordnede og nært sammenbundne mentale aspekter som forutsetninger for den enkeltes strafferettslige ansvarskapasitet. Selv om det nok kan være uenighet om hvordan disse aspektene best forstås, synes det å være enighet om visse grunntrekk ved dem.

Til å begynne med er det grunnleggende at den enkelte må ha en evne til korrekt oppfatning og persepsjon av virkeligheten. Det innebærer at den enkelte gjennom sine sanseinntrykk kan oppfatte verden slik som mennesker normalt sett gjør, eller forventes å gjøre, innenfor en gitt mellommenneskelig referanseramme. ${ }^{46}$ Det betyr, enkelt uttrykt, å se, høre eller kjenne lukten av de ting som (vi andre mener at) finnes og ikke ha uvirkelige inntrykk av syn, stemmer eller lukt.

Opplevelse av verden forutsetter at visse signaler i nervesystemet aktiveres gjennom ulike fysiske stimuli på sansene, slik som lys eller lyd. ${ }^{47}$ På et basalt plan forutsetter det å kunne oppfatte verden riktig at dette sanseapparatet er tilstrekkelig fungerende, hvilket det er hos de aller fleste mennesker. Men ikke en hver mangel er her av betydning. De som er blinde og døve har mangler i denne sammenhengen som innebærer at de, i relasjon til personer som ikke har disse handikappene, ikke har tilgang til en (like) fullstendig oppfatning av verden. Men disse personene har ikke problemer med at de får feilaktige inntrykk av verden, men med at deres virkelighetsoppfatning blir en annen - ufullstendig sett fra den som har evnene. De har også vanligvis innsikt i sitt handikapp og forstår hvordan de må kompensere for dette. ${ }^{48}$

Vår mer kvalifiserte oppfatning av verden beror videre på hvordan vi (kognitivt) organiserer, identifiserer og tolker informasjon fra sansene og på hvordan vi reflekterer over hvordan virkeligheten er. Virkelighetsoppfatning anses altså ikke å basere seg alene på «rene» reaksjoner på sanseinntrykk, men beror på hvordan vårt begrepsapparat, erfaringer og forventninger - til sist også våre «filosofiske» evner - innvirker på vår forståelse av verden.

Vår oppfatning av virkeligheten forutsetter med andre ord en evne til å kunne forstå eller begripe virkeligheten. ${ }^{49}$ Evnen består i stor grad av å kunne systemati- 
sere eller sortere ulike sanseinntrykk med hjelp av begreper og språk. ${ }^{50}$ Gjennom denne evnen kan den enkelte gi sanseinntrykkene «mening» ved å begripe og «sette ord på dem». På denne måten kan vi «se» mennesker, trcer eller hunder og forstå deres plass i verden - og ikke bare fornemme verden ut fra våre inntrykk av den sånn som veldig små barn uten noe språk må gjøre. Denne evnen kan hevdes å omfatte forståelsen av samfunnets «moralske» normer, i betydningen de mellommenneskelige ideer og begreper som uttrykker vurderinger om verdens beskaffenhet - slik som om hva som er «godt», «ondt», «rett» og «feil». Evne til å begripe virkeligheten utvikles vanligvis suksessivt hos den enkelte og forventes i alminnelighet ved å være fullt utviklet ved (straff)myndig alder.

Det er imidlertid ikke tilstrekkelig for strafferettslig ansvarskapasitet å kunne begripe virkeligheten. Det kreves dessuten at man kan «anvende» sin forståelse av virkeligheten til å gjøre riktige valg om hvordan man bør handle. Den fornuftskapasitet som straffansvar forutsetter kan mer presist anses å forutsette at den enkelte kan identifisere og skape grunnlag - handlingsmotiv - for å handle eller ikke handle på en viss måte. Fornuftskapasiteten kan dermed anses å forutsette en viss kapasitet til å tenke koherent, gjennom å kunne sammenlikne og fremfor alt generalisere ulike premisser.

Det betyr også å kunne ha og anvende tankeregler, slik som regler om at det ikke bare er feil å være slem mot meg men mot mennesker generelt. Med hjelp av en slik evne kan den enkelte også korrigere sine egne «umoralske» impulser og fordømme umoralske handlinger. $\AA$ drepe et annet menneske for egen vinnings skyld fremstår eksempelvis for de aller fleste som vanskelig å gi holdbare begrunnelser for. Når alt kommer til alt bygger den strafferettslige ansvarskapasiteten således på evnen til å kunne identifisere og konstruere riktige grunnlag som utgangspunkt for ens handlinger. ${ }^{51}$

Uten de grunnleggende evnene til å oppfatte og begripe verden gir det neppe mening å tale om evne til å gjøre vurderinger som grunnlag for sine handlinger. Disse ulike disposisjonene er også nært forbundet og det virker vanskelig å atskille dem som faktorer av betydning for den enkeltes ansvarskapasitet. Man kan neppe bedømme om sanseinntrykk er korrekte eller ikke uten å bygge på visse begreper om verden. På samme måte virker evnen til riktige vurderinger å kunne spille inn på de øvrige evnene. Til slutt er det nok på bakgrunn av et komplekst samspill mellom disse ulike evnene som den enkelte kan konstruere, forstå, vurdere og prioritere mellom sine handlingsmotiv - og således anses ansvarlig for de handlinger som baseres på disse. ${ }^{52}$ Straffansvarlig handlemåte forutsetter både at man kan erfare og forstå sine omgivelser, som handlingskonteksten, og kunne skape normer for hvordan man skal respondere på denne. 
Selv om disse disposisjonene er nært knyttet til hverandre anses det likevel meningsfullt til å atskille dem. Gjennom å atskille dem, kan disposisjonene benyttes til å utvikle en mer differensiert fremstilling om tilregnelighetens vesen, og for å kunne peke på de mangler som har en slik betydning at de bør medføre strafferettslig utilregnelighet.

\subsection{Tilregnelighetens videre konkretisering}

Med utgangspunkt i de overordnede forutsetningene for ansvarskapasitet kan de egenskaper som kreves for tilregnelighet konkretiseres nærmere. Dette er imidlertid en krevende oppgave. Om man skal forklare alle sider ved de egenskaper som tilregnelighet forutsetter må man redegjøre for stort sett hele menneskets vesen. Det inkluderer alle de diskusjoner som har blitt ført innenfor ulike felt om hvordan mennesket (som handlende vesen) best skal forstås.

Tilregnelighetsspørsmålet knytter seg særlig til problemstillinger innenfor medisin, psykologi og filosofi som hver og én har stor bredde og kompleksitet. Et eksempel er diskusjonen innen psykologien rundt de såkalte eksekutive funksjonene og betydningen disse har for individets kognitive evner. De eksekutive funksjonene anses å være lokaliserte i hjernens frontallapper og omfatter de mentale prosesser som er involverte når vi gjør aktive valg og handlinger ${ }^{53} \mathrm{Et}$ annet eksempel er diskusjoner og forskning som omhandler forholdet mellom individets (manglende) empatiske evner og personlighetsforstyrrelser. Disse diskusjonene er hver for seg svært omfattende og likevel bare et lite utsnitt av de diskusjoner som berører tematikken. Til slutt gir også tilregnelighetsbegrepets metafysiske utgangspunkter stor plass for ulike filosofiske forklaringsmodeller av tilregnelighetens nærmere innhold.

I strafferettsteorien har man vært seg bevisst utfordringen det er å skulle konkretisere egenskapene som tilsier tilregnelighet. ${ }^{54}$ Kanskje man derfor heller har diskutert og konkretisert tilstander som gir grunnlag for å konstatere manglende tilregnelighet. Med dette som bakgrunn skal vi nå søke å identifisere og avgrense relevante utilregnelighetstilstander.

\section{Utilregnelighet}

\subsection{Utgangspunkter for å identifisere de utilregnelige}

Utilregnelighet som rettslig fenomen relaterer alltid til en handling, det vil si til et eller flere lovbrudd som aktualiserer spørsmål om straffansvar. ${ }^{55}$ Om utilregnelighet skal frita fra straffansvar må tilstanden derfor også foreligge på gjerningstidspunktet. 
Strafferettens utgangspunkt er som nevnt at individer har ansvarskapasitet - er tilregnelige. Den forklarer i de fleste tilfeller forbrytelser med at ansvarsevnen $i k$ ke har blitt tatt $i$ bruk og ikke med at denne evnen brister eller mangler. Dette strafferettslige utgangspunktet virker også å være fundamentalt for den menneskelige selvforståelsen og for det mellommenneskelige samvær. Det er en vanlig oppfattelse at mennesker som har handlet ufornuftig, dumt eller klanderverdig, kunne ha handlet annerledes. Reaksjonen på en umoralsk handling er vanligvis ikke å hevde at den som har foretatt den er utilregnelig, men å påpeke den manglende holdbarheten til den handlendes motiv og å klandre vedkommende for handlingen. På denne måten appellerer man til vedkommende som deltaker $i$ et moralsk fellesskap. Det å bli forstått som et ansvarlig menneske er i stor grad en forutsetning for å være en fullverdig samfunnsborger.

Det er derfor ikke uproblematisk uten videre å påstå at en gjerningsperson er utilregnelig. Å mene at noen er utilregnelig innebærer en slags umyndighetserklæring av vedkommende. Det er en påstand om at strafferettens standardmodell om det frie og fornuftige individ er en inadekvat forklaringsmodell for denne gjerningspersonen. ${ }^{56}$ Strafferettens utgangspunkt om individets ansvarskapasitet fyller her funksjonen av å beskytte den enkelte mot en slik umyndiggjøring.

\subsection{Utgangspunkter om relevansen av psykisk lidelse}

Psykisk lidelse kan således ikke uten videre legges til grunn for å frita en gjerningsperson fra ansvar. Tradisjonelt har utilregnelighet bare vært aktuelt i relasjon til psykiske avvikstilstander som har hatt sterk innvirkning på den enkeltes evner - slik som psykose ifølge gjeldende norsk strafferett. ${ }^{57}$ Argumentet om at psykisk syke ikke i for stor grad skal fratas retten til å ta ansvar for sine handlinger uttrykkes også i tilregnelighetsdebatten. ${ }^{58}$

På et mer grunnleggende plan er en psykisk avvikstilstand heller ikke som sådan tilstrekkelig for utilregnelighet. Utilregnelighetsbegrepet tar utgangspunkt i rettslige forutsetninger om ansvarskapasitet, og ikke i medisinske forståelser og klassifikasjoner av psykiske avvikstilstander. Den rettslige reguleringen forutsetter riktignok at utilregnelighet kan utledes fra medisinsk anerkjente tilstander. Denne forutsetning er imidlertid betinget av at gjerningspersonen ikke bare kan betraktes som psykologisk/medisinsk avvikende men til sist også som rettslig avvikende - utilregnelig. ${ }^{59}$ Det er den eventuelle innvirkning som en psykisk lidelse kan anses å ha på den enkeltes ansvarskapasitet i en gitt handlingskontekst og i et gitt handlingsøyeblikk som prinsipielt er det avgjørende.

Psykisk lidelse som grunn til utilregnelighet har visse særtrekk i relasjon til de utilregnelighetsgrunnene som handler om lav alder, utviklingshemming og bevis- 
sthetsforstyrrelser. En person som er utilregnelig (bare) på grunn av psykisk lidelse anses å ha utviklet slike fornuftsevner som kreves for straffansvar og anses også vanligvis å ha bevissthet om sine handlinger. Psykisk lidelse blir primært relevant som utilregnelighetsgrunnlag fordi at den på en negativ måte tilfeldig eller mer varig kan «ta over» den enkeltes tenkning uten at det går ut over dennes handlingsevne.

Her har forskning innen medisin og psykologi bidratt til muligheten å konkretisere hvilke psykiske lidelser og avvik som kan innebære utilregnelighet. Med utgangspunkt i slik forskning har særlig de lidelser som innebærer mangler i den enkeltes evner til realitetsoppfatning og realitetsforståelse, og som på denne måten setter ansvarskapasiteten ut av spill, blitt ansett som mulige utilregnelighetstilstander.

Psykosen har i dette henseende blitt stående i sentrum for strafferettens regler om utilregnelighet ved psykisk lidelse. Det psykotiske individet anses fra «normalperspektivet» å oppfatte seg selv, andre eller omverdenen på en fullstendig urealistisk og ubegripelig måte. Det kan skyldes hallusinasjoner som skaper feilaktige persepsjoner av virkeligheten, vrangforestillinger som gir opphav til feilaktige handlingsmotiv, eller andre typer av funksjonsmangler som gjør at den enkelte ikke på en «normal» måte kan identifisere eller konstruere handlingsmotiv. ${ }^{60}$ Den psykotiske kan også betraktes som en som er ufri og ikke lenger «herre over sine egne handlinger». ${ }^{61}$

I identifiseringen av hvem som skal regnes som utilregnelige er det et viktig spørsmål om det finnes andre tilstander som, på samme måte som psykosen, kan anses å innebære at den enkeltes ansvarskapasitet settes ut av spill. Det er også viktig å ta stilling til om en psykosetilstand, eller andre tilstander som anses å kunne innebære utilregnelighet, også alltid gjør det - slik at den som er psykotisk på et gitt tidspunkt må anses utilregnelig i relasjon til alle handlinger som han eller hun foretar på dette tidspunktet. Som vi skal komme tilbake til er disse spørsmålene sentrale i valget mellom et blandet og medisinsk prinsipp som grunnlag for en utilregnelighetsregel.

Utilregnelighet ved psykisk lidelse kobles som allerede berørt iblant til en manglende evne til å kontrollere handlingene sine, ofte som et resultat av imperative hallusinasjoner (befalende stemmer). ${ }^{62}$ Mange land har også utilregnelighetsregler med kriterier om gjerningspersonens mulighet til å kontrollere sine handlinger. Det er imidlertid problematisk å koble subjektivt opplevd tvang forårsaket av psykisk lidelse til bristende handlingskontroll, som ansvarsbefriende omstendighet. ${ }^{63}$ Strafferetten opererer med høyt stilte forventninger til den enkelte om å kunne «skjære gjennom» og handle riktig også i situasjoner som er karakterisert 
av stort emosjonelt og mentalt press. Det finnes også flere typer av opplevd «tvang» som ikke kan utgjøre unnskyldende omstendigheter i strafferetten, slik som abstinens eller seksualdrift. Derfor blir det vanskelig å forklare hvorfor nettopp tvang forårsaket av psykisk lidelse skal frita fra ansvar. Det lar seg neppe gjøre å begrunne forskjellig strafferettslig regulering beroende på om tvangen forårsakes av psykologiske, biologiske eller miljømessige faktorer. Det sentrale spørsmålet bør i stedet være hvor sterk tvang det kan være tale om før det blir urimelig å ansvarliggjøre en gjerningsperson - uansett hva årsaken er.

Et særlig omdiskutert spørsmål er i hvilken utstrekning psykiske lidelser som primært innebærer empatimangler skal kunne innebære utilregnelighet. Denne diskusjonen omhandler særlig fenomenet psykopati. ${ }^{64}$ Mangler i empatiske evner kan være relevante $i$ et utilregnelighetsperspektiv ettersom slike mangler kan ha betydning for å kunne identifisere og konstruere moralske problemstillinger, for eksempel relatert til uriktigheten i å krenke andre. ${ }^{65}$ Strafferettens prinsipper om klander og skyld bygger til sist på at den enkelte har moralsk fornuftskapasitet og kan identifisere og respondere på moralske grunner. Det kan derfor argumenteres for at psykiske avvikstilstander som kjennetegnes ved manglende empatiske evner bør kunne innebære utilregnelighet. ${ }^{66}$

Det er imidlertid ikke uproblematisk å kople empatimangler til manglende moralsk kapasitet, som selvstendig grunnlag for utilregnelighet. I dette feltet møter sykdom/biologi som forklaringsgrunnlag ondskapens problem. ${ }^{67} 22$. juli-saken satte også lyset på den vanskelige skillelinjen mellom handlinger som er ideologisk motiverte og handlinger som er motiverte av en psykisk avvikstilstand. Uten empiriske holdepunkter får vi store problemer med å skille den som kan unnskyldes som utilregnelig fra den som kan klandres for sine feilaktige handlinger. Som vi har sett finnes det $\mathrm{i}$ hvert fall $\mathrm{i}$ visse tilfeller holdepunkter for å konstatere mangler i de mer grunnleggende evnene til korrekt oppfatning og forståelse av virkeligheten. En person med slike mangler vil man nok også intuitivt oppleve som utilregnelig. Men det er vanskeligere å argumentere for at empatiske mangler setter den enkeltes ansvarskapasitet ut av spill på en slik måte at det skal være tale om strafferettslig utilregnelighet. Samspillet mellom empatiske og kognitive evner som grunnlag for den enkeltes handlinger er komplekst. Det råder også kontrovers rundt det mer filosofiske spørsmålet om den enkeltes moralske fornuftskapasitet i det hele tatt er betinget av tilstedeværelsen av visse følelser.

Det kan i tillegg argumenteres for at en person som ikke har evnen til å identifisere og konstruere moralske problemstillinger, og ikke kan oppleve moralske dilemmaer, likevel kan forventes å forstå og innrette sine handlinger etter strafferettens normer. Strafferetten innrettes nemlig ikke generelt på det mellommenne- 
skelige samværet, men forbyr typisk sett bare visse særlig klanderverdige handlinger - og kommuniserer også disse samfunnsnormene gjennom lovgivning. Uten klare holdepunkter for at en gjerningsperson ikke har evne til å forstå og la seg styre av disse grunnleggende normene, bør ikke utilregnelighet komme på tale. Og mer generelt: så lenge det ikke kan påvises at mentale avvik fratar den enkelte evne til å handle riktig, bør man være tilbakeholden med å gi forrang til en medisinsk forklaringsmodell for menneskets handlinger fremfor strafferettens forklaringsmodell om ansvar.

Dermed kan vi oppsummere med at strafferetten bygger på at voksne mennesker er tilregnelige, og stiller dem til ansvar når de har handlet galt. Tilregnelighet relaterer i hovedsak til den enkeltes fornuftskapasitet og mangler i denne kan innebære utilregnelighet. Skal en straffemyndig gjerningsperson anses utilregnelig på grunn av psykisk lidelse, må det på handlingstidpunktet foreligge slike åpenbare mangler at det ikke gir mening å klandre vedkommende. Strafferettens tilregnelighetslære har her fătt en konsentrasjon omkring de avvikstilstander som er så alvorlige at de innebærer (eller kan innebære) at den enkelte ikke har en korrekt oppfatning og forståelse av virkeligheten - og dermed ikke heller kan tenke og handle fornuftig slik som tilregnelighet og straffansvar forutsetter. Med utgangspunkt i denne avklaringen skal vi nå se nærmere på utformingen av strafferettens utilregnelighetsregler.

\section{Fra begrep til regler: utgangspunkter for reglenes utforming}

Utgangspunktet for strafferettens utilregnelighetsregler er at de skal avspeile de underliggende begrepene om tilregnelighet og utilregnelighet. Det betyr at reglene skal være tilstrekkelig treffsikre til å identifisere de som ikke kan klandres, slik at området for ansvarsfrihet verken blir for lite eller for stort. Samtidig må reglene være praktisk anvendelige for rettens aktører og forsvarlige i relasjon til reglenes konsekvenser i og utenfor rettssystemet. Det er av særlig betydning å vurdere konsekvensene av ulike løsninger for individenes stilling som rettssubjekt.

Gjennom at en utilregnelighetsregel ikke bare skal være treffsikker, men også anvendelig og forsvarlig, gir omsettingen fra begrep til regel plass for mange andre argumenter enn de som handler om selve betydningen av tilregnelighet. ${ }^{68}$ Som vi skal se i det videre handler disse argumentene i stor utstrekning om strafferettssystemets funksjon som regelsystem og samfunnsinstitusjon.

Målsetningene om treffsikkerhet, anvendelighet og forsvarlighet står i et visst spenningsforhold til hverandre, og det kan være vanskelig fullt ut å realisere dem alle. Sentralt er at rettens karakter av å være et institusjonalisert normsystem bærer med seg visse grunnforutsetninger. Rettssystemet karakteriseres av at det til 
enhver tid tar standpunkt i faktiske, normative konflikter gjennom å fatte endelige avgjørelser over hva som er (rettslig sett) riktig - for eksempel om det er riktig å unnskylde en person som har begått et lovbrudd. De regler som strafferetten stiller opp må rent praktisk kunne legges til grunn for slike avgjørelser.

I en rettstat må reglene dessuten gjelde generelt, ikke omhandle enkeltpersoner, og sikre forutberegnelighet i rettsanvendelsen gjennom at like tilfeller behandles likt. Kravet om forutberegnelighet innebærer også et krav på så klare og presise regler som mulig. Dette betyr til sist at strafferettens regler må redusere virkelighetens faktiske og verdimessige kompleksitet og kontroverser til generelle, forutberegnelige og anvendelige regler. ${ }^{69}$ Tilregnelighetsspørsmålet relaterer til en stor kompleksitet og et stort antall kontroverser innen ulike disipliner. Likevel må en ved utformingen av strafferetten ta standpunkt og angi at bestemte tilstander, egenskaper eller mangler kvalifiserer for utilregnelighet. Derfor må vi ta med oss at det finnes en iboende problematikk for lovgiveren $\mathrm{i}$ å utforme en utilregnelighetsregel som på samme tid er treffsikker, praktisk anvendelig og forsvarlig. $^{70}$

\section{Sentrale lovgivningstekniske overveielser}

Et rettslig utilregnelighetsinstitutt kan utformes på mange ulike måter og variasjonsmulighetene fremstår nærmest som ubegrensede. Det er også mange ulike meninger om hvordan den rettslige avgrensningen av de utilregnelige skal gjøres, noe som blant annet ved avspeiler seg i at ulike land ofte har (noe) ulike rettslige løsninger. ${ }^{71}$

En første skillelinje ligger allerede i hvorvidt en skal ha utilregnelighetsregler i straffelovgivningen. Som alternativ kan vilkår for tilregnelighet utvikles og forankres i rettspraksis. Tradisjonen i norsk strafferett er imidlertid å ha regler i straffeloven for når utilregnelighet og ansvarsfrihet kan inntre. Denne tradisjonen kan fra et legalitetsperspektiv anses adekvat og tas som et utgangspunkt i det følgende.

Spørsmålet er da hvordan vilkår for utilregnelighet skal utformes. I lyset av historiske og komparative undersøkelser kan visse grunnstrukturer og idealtypiske varianter fremheves. Disse ulike typetilfellene koples i litteraturen vanligvis til det medisinske eller biologiske prinsipp, det psykologiske prinsipp og det blandede prinsipp..$^{72}$

Regler som bygger på et medisinsk prinsipp definerer utilregnelighet bare $\mathrm{i}$ termer av visse medisinske eller biologiske kjennetegn, slik som eksempelvis en viss sykdomstilstand. Ifølge en slik regelkonstruksjon er det tilstrekkelig at denne tilstanden foreligger på handlingstidspunktet for at gjerningspersonen skal anses 
utilregnelig. Straffeloven $\S 44$ gir uttrykk for et medisinsk prinsipp gjennom å knyte ansvarsfrihet til det å være «psykotisk».

Ifølge det psykologiske prinsippet defineres utilregnelighet i stedet gjennom tilstandens betydning og innvirkning på gjerningspersonen. En regel som bygger på dette prinsippet forsøker således mer direkte å avspeile utilregnelighetens meningsinnhold. I samsvar med strafferettens tilregnelighetslære anvendes her ofte innsiktskriterier om gjerningspersonens manglende evne til innsikt i handlingens (moralske og rettslige) betydning og kontrollkriterier om gjerningspersonens manglende evne til å styre sine handlinger.

Psykologiske kriterier kan, men må ikke, anvendes i tillegg til en definisjon av en viss (medisinsk) tilstand. De fleste stater opererer da også med blandede prinsipper som både definerer de tilstander som kan forårsake utilregnelighet og de effekter av disse tilstandene som dessuten må foreligge for at utilregnelighet og ansvarsfrihet skal inntre.

En regelkonstruksjon med et rendyrket psykologisk prinsipp, som ikke knyter utilregnelighet til noen spesifikk tilstand (som psykisk sykdom) ses det bort fra i den videre diskusjonen. En slik regel har visse prinsipielle fordeler gjennom at den medgir at alle som har visse mangler skal anses utilregnelige, uansett årsaken til disse manglene. Samtidig gjør nettopp denne åpenheten en slik regel praktisk svært vanskelig, ettersom den ikke avgrenser de utilregnelige, men flytter denne grensedragning helt til domstolen.

M'Naughten-reglene som ligger til grunn for mange av de amerikanske statenes regelverk er et eksempel på anvendelsen av et blandet prinsipp. ${ }^{73}$ Disse reglene lar gjerningspersonen være ansvarsfri der vedkommende på grunn av psykisk sykdom ikke innså gjerningens natur eller kvalitet og dersom han innså det, at han ikke innså at det han gjorde var galt - og opererer kun med innsiktskriterier som psykologiske kriterier. I Sverige har det imidlertid blitt lagt fram et lovforslag, der det foreslås en regel som bygger på et blandet prinsipp og som omfatter både innsiktskriterier og kontrollkriterier; om at gjerningspersonen på grunn av visse avvikstilstander manglet evne til å innse gjerningens betydning eller $\stackrel{a}{a}$ tilpasse sine handlinger etter en slik innsikt. ${ }^{74}$

En regel som bygger på et blandet prinsipp kan i tillegg til, eller som et alternativ til, psykologiske kriterier inneholde kausalitetskriterier. Slike kriterier fremhever typisk sett krav på sammenheng mellom avvikstilstand og handling. Dansk rett fremhever imidlertid i Straffeloven $\S 16$ i stedet et krav på sammenheng mellom tilstand og utilregnelighet: «Personer der på gerningstiden var utilregnelige på grund av sindssykdom eller tilstande, der må ligestilles hermed straffes ikke.» Denne regelen avviker fra den typiske konstruksjonen av et blandet 
prinsipp gjennom ikke å anvende psykologiske kriterier for å definere området for ansvarsfrihet. I stedet bygger regelen på muligheten for et mer fritt domstolsskjønn, gjennom å overlate til domstolen nærmere å konkretisere kriterier for utilregnelighet. $^{75}$

I utformingen av utilregnelighetsregler er det overordnede valget mellom de ulike modellene sentralt ettersom de fører til vesensforskjellige regelkonstruksjoner. Samtidig skal forskjellen mellom et medisinsk og et blandet prinsipp ikke overdrives. Et medisinsk prinsipp kan begrunnes ut fra nøyaktig samme utgangspunkter om utilregnelighet som et psykologisk prinsipp. Begrunnelsen for «psykotisk» som kriterium i et medisinsk prinsipp kan eksempelvis være at en sånn tilstand anses å innebære at evner til forståelse og handlingskontroll mangler.

Valget mellom et medisinsk og blandet prinsipp må derfor også forstås som et reguleringsteknisk valg og ikke nødvendigvis (bare) som et uttrykk for ulike syn på utilregnelighetens vesen. En annen sak, som vi skal komme tilbake til, er at dette valget kan få konsekvenser som må vurderes i lovgivningsarbeidet, slik som i spørsmål om rollefordelingen mellom sakkyndige og rettskyndige. Men først skal vi se litt nærmere på grunnvilkåret om treffsikkerhet og dets betydning for valg av regelkonstruksjon.

\section{Grunnvilkåret om treffsikkerhet}

Strafferettens utilregnelighetsregler må kunne legges til grunn for en adekvat avgrensning av de som kan fritas fra straffansvar som utilregnelige. En regel som inneholder psykologiske kriterier og/eller kausalitetskriterier fremheves ofte som mer treffsikker enn en regel som definerer utilregneligheten kun gjennom tilstandskriterier. ${ }^{76}$ Dette argumentet har en viss bærekraft. En regel som inneholder psykologiske kriterier eller kausalitetskriterier kan mer direkte fange inn betydningen av utilregnelighet. Det viktigste er at en slik regel, i samsvar med hva straffansvar handler om, kan koble gjerningspersonens manglende ansvarskapasitet til utføringen av den handling som utgjør lovbruddet.

Det kan imidlertid argumenteres for at også en regel som bygger på et medisinsk prinsipp kan være treffsikker. I hvert fall synes det å finnes tilstander som kan anvendes som kriterier i en slik regel som ligger svært nær strafferettens forståelse av utilregnelighet. Som beskrevet er psykosetilstanden sentral i dette henseende, ettersom den som er psykotisk kan forstås som en person hvis ansvarskapasitet har blitt satt ut av spill.

Spørsmålet om treffsikkerhet skal kanskje i stedet stilles som et spørsmål om en regel kan være treffsikker uten å anvende psykologiske kriterier og/eller kau- 
salitetskriterier - slik som mange stater gjør. Går det an å skille de tilregnelige fra de utilregnelige bare ved hjelp av tilstandskriterier?

Et omdiskutert spørsmål er om det finnes tilstander hvis eksistens på et gitt tidspunkt alltid innebærer at en gjerningsperson ikke skal klandres strafferettslig for noen av de handlinger han eller hun utfører. Bør for eksempel den som befinner seg i en psykosetilstand alltid anses utilregnelig og fri fra straffansvar for sine handlinger?

Det er problematisk i denne sammenhengen at de fleste avvikstilstander kan graderes alt ettersom symptombelastningen, funksjonssvikten og til sist ansvarskapasiteten varierer. Fra et klinisk perspektiv kan eksempelvis en psykose være mer eller mindre gjennomgripende, slik at det gir mening å si at en person er mer psykotisk enn en annen. ${ }^{77}$

Et grunnproblem i relasjon til psykosebegrepet er at det i stor grad mangler entydige og klare (medisinske) kriterier som angir hva som kreves for å vaere psykotisk, og som angir hvilke symptomer og svikter som skal foreligge og med hvilken styrke. De kriterier som har blitt utarbeidet refererer primært til de ulike sykdommer (jf. psykoselidelser) som har psykosetilstanden som en del av sykdomsbildet. $^{78}$ De symptomer som i denne sammenhengen angis som kjennetegn på psykose, slik som vrangforestillinger og hallusinasjoner, gir egentlig ikke noe fullstendig bilde av hva det er å være psykotisk. ${ }^{79}$

Treffsikkerhetsproblemene som følger av en regel basert på et medisinsk prinsipp kan til en viss grad avhjelpes gjennom at de tilstandskriterier som angis i regelen er nøye presiserte, slik at det eksempelvis blir tydelig hvilken symptomtyngde eller funksjonssvikt som kreves for at en tilstand skal innebære utilregnelighet. Et eksempel på en slik presisering finnes i NOU 1990:5. Der ble det foreslått at strl. § 44 skulle angi at den «som på handlingstiden var psykotisk og dermed uten evne til realistisk vurdering av sitt forhold til omverdenen» skal fritas fra straff. ${ }^{80}$ Denne typen formuleringer kan langt på vei tjene den presiserende funksjon som tradisjonelle psykologiske kriterier gjør.

En regel basert på et medisinsk prinsipp behøver altså ikke formulere kriterier for ansvarsfrihet bare i utpregede medisinske termer. Straffeloven kunne også helt utelukke termen «psykotisk» og bare fastslå at «den som på handlingstiden var uten evne til realistisk vurdering av sitt forhold til omverdenen straffes ikke», eller på annen måte presisere de tilstander som skal innebære utilregnelighet. ${ }^{81}$

La oss så gå ut ifra at det finnes tilstander, som eksempelvis psykose og/eller realitetsbrist, som innebærer at en gjerningsperson alltid er utilregnelig i relasjon til handlinger som begås i tilstanden. Da blir spørsmålet om det finnes andre tilstander som også kan, men ikke nødvendigvis må, lede til utilregnelighet. Finnes 
det ikke også andre personer enn de psykotiske som bør kunne anses å mangle kapasitet til å være strafferettslig ansvarlige for sine handlinger? Eller, med referanse til realitetsbrist; finnes personer som ikke har så gjennomgripende realitetsbrist som ved psykose, men som likevel ikke bør holdes ansvarlige?

Det er særlig denne problematikken som reiser spørsmålet om en utilregnelighetsregel bør omfatte kun tilstandskriterier. Drøftelsen av om tilstandskriterier kan anses tilstrekkelig var også bakgrunnen da en fakultativ ansvarsfrihetsregel ble foreslått i NOU 1974:17 og NOU 1990:5. ${ }^{82}$ Forslaget gikk ikke ut på det skulle anvendes psykologiske kriterier, men løste isteden problemet ved å åpne for et dommerskjønn i spørsmålet om andre enn de psykotiske skulle anses utilregnelige. Som vi skal se på videre i avsnitt 9 kan en slik skjønnsmargin gå på bekostning av andre hensyn, herunder forutberegnelighet og rettssikkerhet i rettsanvendelsen.

Til slutt må rettsregler som vi har sett likevel alltid bygge på reduksjoner av virkelighetens kompleksitet. Det kan her noteres at ansvarsfrihet for barn i mange stater konstrueres gjennom bare en tilstandsdefinisjon, slik at barn under en viss aldersgrense kategorisk fritas fra straffansvar. Selv om den aldersgrensen, slik som i norsk rett, er 15 år kan det ikke utelukkes at det finnes 14-åringer som faktisk har ansvarskapasitet og 17-åringer som ikke har det. Men 15 år fremstår likevel som et rimelig treffsikkert utgangspunkt og en praktisk og rettssikker lovteknisk løsning.

Det kan også problematiseres om det i det hele tatt går an å konstruere en utilregnelighetsregel for ansvarsfrihet ved psykisk lidelse som ikke kan kritiseres for å kunne omfatte mer eller mindre enn det burde. I dette henseendet kan også treffsikkerheten i regler som inkluderer psykologiske kriterier og/eller kausalitetskriterier problematiseres.

Det er langt ifra gitt hvilke kriterier en slik regel i så fall skal omfatte, og hvordan disse skal utformes. En særlig problemstilling berører her relasjonen mellom regelens tilstandskriterier og psykologiske kriterier. Med referanse til de psykologiske kriterier som ofte anvendes i lovgivning kan det ofte reises spørsmål om forekomsten av en gitt avvikstilstand egentlig er avgjørende for at de effekter som kriteriene utpeker skal kunne inntre. Dersom også andre tilstander enn de som angis i en regel anses å kunne ha virkninger som denne regelen utpeker, er spørsmålet hvorfor ikke også disse tilstandene har blitt inkludert. ${ }^{83}$

I litteraturen diskuteres eksempelvis psykopati, autismespektrumlidelser og ADHD som tilstander som kan innebære manglende evne til å forstå en handlings karakter, men som sjelden omfattes av staters utilregnelighetsregler. Den tydelige koplingen mellom arv, miljø, samfunn og forbrytelser, gjør det vanskelig å isolere 
slike kriterier til bare visse kategorier av psykisk forstyrrede personer. Til slutt virker denne problematikken i stor grad å tvinge regelkonstruksjonen tilbake til rettsanvendelsesnivå og til tanken om en generell regel om utilregnelighet som kan omfatte alle og enhver som oppfyller visse psykologiske kriterier. Mer generelt peker den også på det utfordrende $\mathrm{i}$ - nettopp som for et medisinsk prinsipp å utforme vilkår for utilregnelighet som verken omfatter for mye eller for lite.

Treffsikkerhetsvurderingen ser slik sett ikke ut til å gi avgjørende argumenter for valg av prinsipp ved utformingen av regelen. Begge alternativer rammes av de generelle problemer som ligger i det å skulle utforme en rettsregel. Med dette som bakgrunn skal vi nå se videre på argumenter som handler om reglenes praktiske funksjon og konsekvenser i strafferettssystemet.

\section{Regelens praktiske funksjon og konsekvenser i strafferettssystemet}

\subsection{Regler om utilregnelighet og strafferettssystemets interne funksjon}

Strafferettens utilregnelighetsregler skal ikke bare kunne forsvares som treffsikre. Reglene skal også kunne forsvares med hensyn til hvordan de virker i strafferettssystemet og hvilke resultat de innebærer i praksis. Det betyr at reglene skal kunne fungere i, og forsvares ut fra, den rettslige sammenhengen strafferettssystemet utgjør, som ett system av rettslige normer, institusjoner og aktører. Reglene må passe inn i systemets etablerte ordninger, tradisjoner og prosessøkonomiske rammebetingelser. Ofte vil eksisterende systemstrukturer begrense muligheten til altfor gjennomgripende forandringer.

På et normplan må utilregnelighetsreglene kunne fungere på de premisser som systemets eksisterende regelverk og prinsippstrukturer setter. Det betyr for eksempel at reglenes utforming må vurderes i relasjon til idealer om rettssikkerhet eller premisser for bevisvurdering. På et aktørplan må det vurderes hvilke konsekvenser regelutformingen har for arbeidsoppgavene til og funksjonsdelingen mellom rettens aktører, og for disse aktørenes ressursmessige prioriteringer.

I denne sammenhengen er det viktig at strafferettens tilregnelighetsvilkår rent praktisk kan fylle andre funksjoner i strafferettssystemet enn å avgrense hvem som skal være straffansvarlig. Ifølge straffeloven kan særreaksjoner på visse vilkår idømmes for den som har blitt frifunnet som utilregnelig. ${ }^{84}$ På denne måten gir strafferettens utilregnelighetsregler også - mer indirekte - grunnlag for andre tvangsinngrep enn straff, som også har store konsekvenser for den enkelte. Reglene kan også ha en prosessøkonomisk konsekvens, gjennom å innvirke på avgjørelser om ikke å reise påtale eller å legge ned pågående etterforskning når det finnes mistanke om utilregnelighet og grunnlag for særreaksjon mangler. 
I det følgende skal vi se litt nærmere på noen av de mest sentrale argumentene som forekommer i diskusjonen om utformingen av strafferettens utilregnelighetsregler og som omhandler systemhensyn som de nevnte.

\subsection{Bevishensyn og aktørenes funksjonsfordeling i tilregnelighetsspørsmålet}

Det kanskje mest fremtredende spørsmålet i diskusjonen omhandler funksjonsfordelingen mellom retten og den sakkyndige i avgjørelsen av tilregnelighetsspørsmålet. Dette spørsmålet omhandler også bevishensyn, ettersom det gjelder hvem som skal vurdere og til slutt ta stilling til en gjerningspersons tilregnelighet, og på hvilket grunnlag. Funksjonsfordelingen har særlig betydning for innslaget av rettslige vurderinger, i relasjon til de sakkyndiges konklusjoner om gjerningspersonens mentale tilstand.

I diskusjonen er spørsmålet om funksjonsfordelingen mellom aktørene i stor grad knyttet opp mot valget mellom et medisinsk og et blandet prinsipp. Disse ulike regelmodellene anses typisk sett å gi ulikt rom for sakkyndigekspertise respektive rettslige vurderinger, der det medisinske prinsippet anses å gi den sakkyndige større innflytelse. Diskusjonen i etterkant av 22. juli har i dette henseende reist spørsmålet om strl. § 44 i for stor grad legger avgjørelsen av tilregnelighetsspørsmålet $\mathrm{i}$ hendene på de sakkyndige og deres diagnostiske vurderinger, på bekostning av spillerommet for domstolens egne rettslige vurderinger. Vi skal nå se litt nærmere på argumentet om funksjonsfordeling.

Det er retten som skal avgjøre om tilregnelighet er bevist. ${ }^{85}$ Retten må vurdere bevisene som har blitt lagt frem om gjerningspersonens psykiske tilstand på gjerningstidspunktet, og de sakkyndiges uttalelser vil da stå sentralt. Sakkyndigbeviset har en tilsvarende sentral stilling også i de land som har regler som bygger på et blandet prinsipp. ${ }^{86}$

Det er imidlertid ingen tvil om at en regel som bygger på et medisinsk prinsipp, slik som strl. $\S 44$, i stor grad flytter avgjørelsen av tilregnelighetsspørsmålet inn i den diagnostiske og medisinske sfæren. Om en gjerningsperson ifølge de sakkyndiges vurderinger er å anse som psykotisk vil gjerningspersonen i alminnelighet også anses psykotisk og utilregnelig etter straffeloven. ${ }^{87}$

Som diskutert ovenfor kan dette til slutt gå ut over regelens treffsikkerhet, dersom konsekvensen blir at en gjerningsperson går fri fra straff også i tilfeller der avvikstilstanden egentlig ikke var så inngripende at den kunne begrunne manglende ansvarskapasitet. Et medisinsk prinsipp som ikke anvender termer med sterke medisinske referanser, men mer dagligspråklige termer, inviterer i større grad til mer selvstendige rettslige vurderinger. Termer som ikke har så sterke 
koplinger til den medisinske begrepsverdenen kan også anses å fungere bedre som koblingspunkter mellom diagnostiske og rettslige vurderinger.

Straffelovens medisinske prinsipp innebærer imidlertid ikke bare at rommet for domstolens skjønnsmessige vurderinger blir mindre. Den innebærer også, særlig gjennom bruk av termen «psykotisk», at disse vurderingene til en viss grad flyttes inn i de sakkyndiges sfære. Psykiatriske diagnoser relaterer seg til komplekse tilstander og symptomer, og omfatter alltid vurderinger. Ettersom det i stor grad mangler entydige kriterier for psykose kan spørsmålet om en person er psykotisk eller ikke gis ulike svar av ulike sakkyndige. ${ }^{88}$

Den psykiatriske virksomheten omfatter også flere ulike kliniske og teoretiske perspektiv på hva det er å være psykotisk. ${ }^{89}$ Når de sakkyndige dessuten, slik som i norsk rett, ofte bes om å konkludere om straffelovens kriterier om psykose og utilregnelighet er oppfylte, må de dertil gjøre en juridisk vurdering. ${ }^{90}$ På dette punkt kan det problematiseres om den diagnostiske og den juridiske vurderingen kan smitte over på hverandre, slik at det diagnostisk konkluderes med psykose i de tilfeller der den sakkyndige mener at utilregnelighet foreligger. ${ }^{91}$ Denne muligheten gir argument for at de sakkyndige ikke skal konkludere om rettslige premisser, men bare opplyse retten om diagnostiske vurderinger og konklusjoner. Det betyr at dommeren skal etterspørre de sakkyndiges uttalelser om eksempelvis gjerningspersonens funksjonssvikt, symptombelastning og avvikstilstander på handlingstidspunktet, men selv vurdere om gjerningspersonens tilstand er så inngripende at det svarer mot den rettslige standarden for utilregnelighet. En slik ordning beror på hvordan de sakkyndiges mandat utformes og er mulig innenfor rammen for eksisterende utforming av straffeloven.

En regel som bygger på et blandet prinsipp unngår i stor grad de innvendinger som fremheves i diskusjonen om det medisinske prinsippet. Gjennom å inneholde kriterier for forbindelsen mellom sykdom og handling, og for gjerningspersonens evne til å forstå eller kontrollere nettopp den aktuelle handlingen, gis det større rom for domstolens vurderinger. På denne måten fremheves også tydeligere den moralske dimensjonen om gjerningspersonens klanderverdighet og skyld i tilregnelighetsspørsmålet - og fokuset på sykdom og diagnose trer noe tilbake. I forhold til å gi grunnlag for funksjonsfordeling representerer den danske regelen en særskilt modell. Denne regelen tydeliggjør rollefordelingen mellom det medisinske og det rettslige gjennom en distinksjon mellom tilstand og utilregnelighet og gir dermed også dommeren mulighet for et mer fritt skjønn.

Selv om en regel som bygger på et blandet prinsipp kan anses fordelaktig på disse punkter, er den funksjonsfordelingen en slik regel åpner for ikke fri for innvendinger. Mot et psykologisk prinsipp har Randi Rosenqvist her pekt på vanske- 
ligheten for sakkyndige i å påvise en sykdoms effekter overfor en handling i form av manglende innsikt i eller kontroll over handlingen. ${ }^{92}$ Dette argumentet kan riktignok møtes med at det til sist er retten som skal ta stilling til om ansvarsvilkårene er oppfylte. Det kreves heller ikke nødvendigvis at sakkyndige opplyser retten om slike psykologiske effekter, men dette spørsmål skulle kunne overlates helt til en juridisk skjønnsmessig vurdering.

Likevel berører kritikken mot det blandede prinsipp en mer grunnleggende problemstilling. Medisinske fenomen er typisk sett lettere å bevise, også for rettslige aktører, enn metafysiske. Som vi har sett har begrepene om tilregnelighet og utilregnelighet en metafysisk referanse. Når utilregnelighet avgrenses gjennom psykologiske kriterier legges denne metafysiske dimensjonen inn i lovteksten. Hva er det egentlig å forstå og kontrollere en handling? Og hva forutsettes for det? Anvendelsen av slike kriterier i en tilregnelighetsregel innebærer at hver avgjørelse om utilregnelighet må baseres på mer usikre antakelser om et individs evner. Og spørsmålet er hva som gjør dommeren mer egnet enn de sakkyndige til å konkludere i slike spørsmål. ${ }^{93}$

Denne problematikken er en sterk innvending mot et blandet prinsipp med psykologiske kriterier. Problematikken har også relevans for en regel som tillater et mer fritt skjønn i tilregnelighetsspørsmålet, slik som den danske regelen og slik som en fakultativ regel kan innebære. Innvendingen handler til sist om individenes rettssikkerhet og forutberegnelighet når det kommer til på hvilke grunnlag utilregnelighet kan konstateres. En regel som bygger på et medisinsk prinsipp har tross alt den fordelen at den på en forutberegnelig måte kan avgrense området for ansvarsfrihet. Gjennom å knyte utilregnelighet til klart definerte tilstander kommuniseres generelle holdepunkter for domstolens utilregnelighetsvurderinger. Dermed unngås den problematikk som kan ligge i at domstolen, eller sakkyndige, skal gå inn i hvert enkelt tilfelle og uttale seg om en spesifikk gjerningspersons kapasitet til ansvar for sine handlinger. Det er også i lyset av en slik problematikk at utilregnelighet på grunn av lav alder blir avgjort ut fra en fast aldersgrense.

\subsection{Konsekvensene for reaksjonssystemet}

Argumenter om at psykisk syke ikke skal sitte i fengsel kan ikke begrunne strafferettens tilregnelighetsvilkår, ettersom argumentene ikke kan forklare hvorfor en gjerningsperson skal være fri fra ansvar. Likevel er disse argumentene viktige å ta hensyn til i spørsmålet om hvilke konsekvenser en gitt regel får. Grensen mellom den utilregnelige og den tilregnelige trekker en grense mellom frifinnelse og straff. Desto snevrere området for ansvarsfrihet defineres i en utilregnelighetsregel, desto flere psykisk syke vil antagelig måtte sone i fengsel. Og jo videre 
området gjøres, desto flere personer som ikke (lengre) har behov for behandling kan få en dom på særreaksjon - selv om en utilregnelig gjerningsperson ikke nødvendigvis får en slik dom. ${ }^{94}$

I norsk rett skal den som er alvorlig psykisk syk, slik som den psykotiske, ikke sone i fengsel - uansett om personen var tilregnelig på handlingstidspunktet og derfor ble dømt til straff. Straffeprosessloven har regler om soningsutsettelse og straffegjennomføringsloven har regler om at innsatte skal overføres til sykehus dersom det er nødvendig fra et behandlingsperspektiv. ${ }^{95}$

Oppfatningen om at den alvorlig psykisk syke ikke skal sitte i fengsel kan også forstås som uttrykk for et generelt barmhjertighetsprinsipp, som har fått gjennomslag i de fleste rettsstater og også i folkeretten. Det fremgår eksempelvis av de europeiske fengselsreglene at «[p]ersoner som er mentalt syke og hvis mentale helsetilstand er uforenlig med forvaring i fengsel, bør holdes i forvaring i en institusjon spesielt tilpasset formålet». Og dersom slike personer likevel unntaksvis blir forvart i fengsel skal det tas særskilt hensyn til deres helsetilstand og behov. ${ }^{96}$

Hensyn til belastningen det kan innebære for alvorlig psykisk syke å sone i fengsel, gir et tilleggsargument for ansvarsfrihet for psykotiske lovbrytere. Men siden argumentet ikke kan begrunne ansvarsfriheten, kan det heller ikke legges til grunn for å hevde ansvarsfrihet for alle de lovbrytere som har psykiske lidelser, eller som kan lide psykisk i fengsel. Det er, og må nok være, slik at mange av de som (skal) anses tilregnelige og som dømmes til fengselsstraff kan lide av psykisk sykdom som aktualiserer behov for og krav på behandling. ${ }^{97}$

Isteden bør man fremheve tilgangen på adekvat pleie som en allmenn rettighet for den enkelte - som bør diskuteres på tvers av distinksjonene i reaksjonssystemet. Interessene av å reagere med straff respektive å gi behandling behøver således ikke å stå i motsetning til hverandre. Uansett om en gjerningsperson skal sone i fengsel, behandles og forvares i rettspsykiatrisk institusjon eller gå fri fra straff gjør et allment krav på akseptabel pleie seg gjeldende.

Diskusjonen bør dessuten se ut over strafferetten og betone preventive tiltak. Trolig har utformingen av - og ressursene til - forvaltningsrettens system for pleie, inngrep og oppfølging ved psykisk sykdom betydning for hvorvidt det begås lovbrudd $-\mathrm{i}$ hvilken grad strafferetten i det hele tatt aktualiseres.

\subsection{Prosessøkonomiske hensyn}

Strafferettssystemets har begrensede ressurser. Det fremtvinger prioriteringer, for eksempel mellom hvilke lovbrudd som skal etterforskes. Ressursene legger også begrensninger på systemets aktører når det kommer til å skulle realisere generelle 
målsettinger slik som tilstrekkelig høy oppklaringsprosent, gjennomstrømmingstid i domstolene eller tilgang til adekvat pleie i fengselsanstaltene.

Strafferettssystemet preges i denne sammenhengen av overbelastning. Kapasitetsproblemene gir argumenter for i valget mellom ulike prinsipielt akseptable løsninger for en utilregnelighetsregel å unnvike endringer som er altfor kostbare for systemet og som krever opplæring og tid for tilpassing. I dette henseende virker det særskilt viktig å vurdere hvordan en tilregnelighetsregel kan virke inn på den sakkyndigpraksis som har blitt utviklet i rettspsykiatrien, med Den rettsmedisinske kommisjon i sentrum, og omkostningene ved eventuelt å etablere nye standarder.

Bevisspørsmålet fremstår som sentralt også i denne sammenhengen. Det gjør også de rettssikkerhetsaspekter som henger sammen med dette spørsmålet, slik som krav på sakens opplysning. Fra et prosessøkonomisk perspektiv skal forenkling av en regels praktiske anvendelse ikke undervurderes. Dilemmaet er at en mer begrepsmessig treffsikker regel, som i mindre grad reduserer tilregnelighetsbegrepets kompleksitet, kan innebære større vansker i rettsanvendelsen.

\section{Regelen fra et samfunnsperspektiv}

\subsection{Betydningen av strafferettens kommunikasjonsaspekt}

Det er ikke bare de praktiske konsekvensene i strafferettssystemet som er relevante i utformingen av en utilregnelighetsregel. En slik regel må også bedømmes i relasjon til den sosiale funksjon strafferettssystemet skal ha og, som et sentralt aspekt av dette, i relasjon til borgernes oppfatninger.

Dette er et sentralt hensyn fordi strafferettssystemet, og rettssystemet mer generelt, har som funksjon å kommunisere, skape og befeste visse samfunnsoppfatninger - slik som oppfatninger om distinksjonen mellom det normale og det unormale eller det syke og det friske. ${ }^{98}$ Systemet bør i så liten grad som mulig kommunisere budskap som resulterer $i$ at ugrunnede negative holdninger mot visse grupper i befolkningen skapes, befestes eller forsterkes.

Her kan det pekes på vekten av i strafferetten å nøye presisere forskjellen mellom medisinske/diagnostiske termer relaterte til psykisk sykdom og juridiske termer relaterte til ansvar og ansvarsevne. ${ }^{99}$ En utilregnelighetsregel bør med andre ord ikke - uriktig - kommunisere at psykisk syke generelt mangler fornuftskapasitet og evne til å handle ansvarlig. Dette kan tale for at man ikke benytter medisinske termer, slik som psykotisk, i straffeloven. I denne sammenhengen kan det også diskuteres hvilken betydning rollefordelingen mellom de sakkyndige og retten har for borgernes tillit til strafferettssystemet. 


\subsection{Sosial ro og borgernes forventninger om straff}

På et mer overordnet plan har strafferettssystemet en viktig (allmennpreventiv) funksjon i forhold til å kommunisere og befeste oppfatninger om forbrytelser som klanderverdige handlinger som kan lede til straff. Strafferettssystemet tar, gjennom å tilskrive ansvar, mer spesifikt stilling i sosiale konflikter. Borgernes tillit til systemet er da sentralt, og grunnleggende oppfatninger om forbrytelser, straff og klanderverdighet er viktige også i forhold til når psykisk lidelse skal føre til ansvarsfrihet.

Argumentet om sosial ro som artikuleres i norsk rett som en del av straffens preventive formål er her særlig interessant. ${ }^{100}$ Argumentet går ut på at prevensjonsformålet, ved siden av at forebygge uønsket adferd, også omfatter å forebygge sosial uro i «kjølvannet av uønsket adferd som likevel måtte skje». Det at lovbrudd blir forfulgt og straffet anses å bidra til at skape trygghet og ro i samfunnet, og slik sett også til at forebygge ny kriminalitet.

Sosial ro-argumentet rommer ikke kun klassiske målsetninger om prevensjon. Argumentet omfatter også perspektiver koplede til den «allmenne rettsfølelsen» og borgernes - og særlig ofrenes - oppfatninger om hvordan systemet skal reagere på lovbrudd. Slike perspektiver har blitt lagt til grunn i praksis, som selvstendige argumenter, og er særlig artikulert innenfor rammen for straffegjennomføringsretten. ${ }^{101}$

I den allmenne opinionen uttrykkes også ofte synspunkter om at (tilstrekkelig) alvorlige forbrytelser skal straffes, uansett gjerningspersonens psykiske tilstand på handlingstidspunktet. Fra et offerperspektiv kan det også stilles spørsmål ved at en lovbryter som har begått alvorlige krenkelser skal gå fri fra ansvar og straff. Særlig etter 22. juli-saken har offerperspektivet vært sentralt i tilregnelighetsdiskusjonen.

Argumenter om straffens preventive formål kan, som det har fremgått, ikke i seg selv begrunne eksistensen av strafferettens tilregnelighetsvilkår. Spørsmålet er imidlertid om, og i hvilken utstrekning sosial ro-argumentet likevel kan ha relevans i spørsmålet om hvordan strafferettens utilregnelighetsregler skal utformes.

Som utgangspunkt bør lovgiveren være forsiktig med å basere regler på argumenter om hva (en ser for seg at) den allmenne rettsfølelsen, eller offerperspektivet, krever - til det er samfunnets kompleksitet for stor. ${ }^{102}$ I stedet bør vurderingen gjøres i relasjon til strafferettssystemets mer overordnede funksjon av å sikre individenes frihet, og balanseringen mellom ulike hensyn for å oppfylle denne funksjonen. 
For å sikre individers beskyttelse på en optimal måte må strafferettssystemet nemlig sikre en rimelig balanse mellom hensyn til effektiv kriminalitetskontroll og hensyn til maktbegrensning. Gjennom kriminalitetskontroll beskytter systemet individene fra krenkende inngrep fra andre individer og gjennom maktbegrensning beskytter systemet individene fra krenkende inngrep fra makthaverne. I et systemperspektiv er det således viktig at det ene hensynet aldri får stå helt tilbake for det andre, slik at resultatet blir at individenes fri- og rettighetsvern svekkes.

En slik balansering omfatter også spørsmålet om den konkrete avgrensningen av de utilregnelige og konsekvensene av denne. Argumenter om å beskytte individer som ikke kunne handle annerledes fra klander og straff må vektes mot argumenter om å beskytte individer fra på uklare grunnlag bli erklært å være uten kapasitet til fornuft og ansvar. Disse argumentene om ansvar skal også balanseres mot argumenter om å reagere på de krenkelser som skjer, og verne både offerets og samfunnets forventninger om adekvat kriminalitetskontroll og bruk av straff.

På denne måten kan også argumentet om sosial ro anses relevant, også som et argument som kan anses å støtte - men ikke begrunne - en snever avgrensning av de «utilregnelige». Sosial ro-argumentet kan imidlertid ikke legges til grunn for et mer individualisert «utilregnelighetssystem», der oppfatninger blant samfunnets borgere tillates å influere avgjørelsen om en gjerningsperson er utilregnelig eller ikke. ${ }^{103}$ Her må strafferettens grunnleggende premisser om skyld være avgjørende, uansett hvor alvorlige handlinger det er tale om.

På dette punktet er det, ikke minst for å ta offerperspektivet på alvor, derfor særlig viktig å se strafferetten i et større system- og samfunnsperspektiv. Allerede i gjeldende rett finnes det mekanismer utenfor strafferetten som tilgodeser offeret. En gjerningsperson som anses strafferettslig utilregnelig kan for eksempel fremdeles bli sivilrettslig erstatningsansvarlig. ${ }^{104}$ Et offer kan således tilgodeses sivilrettslig når den strafferettslige dommen må være en frifinnelse fordi gjerningspersonen ikke oppfylte strafferettens krav om tilregnelighet. Dette kan virke ulogisk, men har sin begrunnelse $i$ at de ulike regelsystemene innen erstatningsretten respektive strafferetten har ulike formål og således ulike regler om ansvar. ${ }^{105}$

\section{Avsluttende anmerkninger}

Så langt er tilregnelighetsvilkårets strafferettslige betydning klargjort. Det er særlig fremhevet at en rekke hensyn må ivaretas ved utformingen av en utilregnelighetsregel. Tilbake står vi igjen med en erkjennelse av at det er vanskelig å skape regler som fullt ut fanger inn strafferettens begrep om utilregnelighet $o g$ samtidig er praktisk anvendelige og rettslig forsvarlige. Ulike regler har ulike styrker og svakheter. 
Noen prinsipielle holdepunkter blir likevel stående. En utilregnelighetsregel skal være treffsikker i relasjon til strafferettens idé om utilregnelighet. Strafferettens grunnspørsmål handler om rimeligheten i å klandre de personer som begår forbrytelser. Kriterier for ansvarsfrihet ved psykisk lidelse skal dermed baseres på overveielsen om når (voksne) gjerningspersoner rimeligvis kan anses å mangle kapasitet til å være strafferettslig ansvarlig for sine handlinger, og skal alltid kunne forsvares på et slikt grunnlag.

Utgangspunktet om individets tilregnelighet er her sentralt i strafferettens ansvarslære, og mer generelt en hjørnestein i rettsstatens verdigrunnlag. Den psykisk syke bør ikke uten videre fraskrives ansvarskapasitet og strafferetten bør ha en snever avgrensing av de utilregnelige. En avgrensning til de tilstander som innebærer at den enkeltes evne til riktig oppfatning og forståelse av virkeligheten settes ut av spill fremstår som adekvat. Her står psykosetilstanden (men ikke nødvendigvis psykoselidelsen eller termen psykotisk) i sentrum. Strafferettens snevre avgrensning av de utilregnelige medfører imidlertid at problematikken relatert til reaksjonsystemets utforming og særlig tilgangen til adekvat pleie bør få stor oppmerksomhet.

Artikkelen har videre handlet om hvordan ulike argumenter om de praktiske konsekvensene av en utilregnelighetsregel påvirker regelens utforming innenfor de ulike prinsipielt akseptable alternativ. Valget mellom et medisinsk og blandet prinsipp har blitt viet oppmerksomhet og det har blitt fremhevet fordeler og ulemper med begge konstruksjonene. Valget av regelkonstruksjon er langt i fra åpenbart.

Ifølge forfatterens oppfatning taler imidlertid særlig forutberegnelighets- og rettssikkerhetshensyn for å ha en (medisinsk) konstruksjon med kun tilstandskriterier. Men da bør de tilstander som skal omfattes av en utilregnelighetsregel presiseres tydeligere enn tilfellet er i dag, særlig med tanke på hvilken art og grad av avvik som skal kreves. Hvis man benytter presiserende kriterier som markerer at en sykdomsdiagnose i seg ikke er tilstrekkelig, blir ikke avstanden til et blandet prinsipp stor. Det kan også diskuteres om termen «psykotisk» bør tas bort fra straffeloven, ettersom denne termen har så sterke koplinger til spesifikke sykdomsdiagnoser og dessuten i praksis er gjenstand for ulike tolkninger. En utilregnelighetsregel bør frita dem som på handlingstidspunktet er i en så inngripende avvikstilstand at det ikke gir mening å klandre dem, uansett om tilstanden medisinsk bedømmes som en psykosetilstand, eller ikke. Under alle omstendigheter bør diagnostiske konklusjoner ikke sammenblandes med hvorvidt rettslige kriterier for utilregnelighet er oppfylte. 
Til sist er det nok viktig å erkjenne at selv om variasjonsmulighetene i hvordan en utilregnelighetsregel kan utformes er mange, så er det ikke sikkert at det praktiske utfallet av de ulike mulighetene er like varierende. Det finnes i hvert fall grunn til å tro at strafferettssystemets rettstradisjon har en viss styrende effekt på hvem som anses utilregnelige. Regelens praktiske funksjon i systemet og de samfunnsvurderinger den relaterer til vil nok også ha stor betydning i forhold til om den godtas, eller om den blir gjenstand for kritikk og (nye) endringsforslag.

\section{Noter}

1. Artikkelen er i store deler skrevet under utredningsperioden for «Tilregnelighetsutvalget», oppnevnt 25. januar 2013. En lengre versjon av artikkelen er publisert i NOU 2014:10, Skyldevne, sakkyndighet og samfunnsvern. Takk til utvalgsleder, utvalgsmedlemmene og sekretariatet for diskusjoner, særlig takk til Paul Leer Salvesen, Arne Johan Vetlesen og Anders Løvlie for kommentarer på teksten. Utenfor utvalget takk til Jørn Jacobsen, Randi Rosenqvist og Erik R. Hauge for verdifulle kommentarer og diskusjoner. Takk til Jan Tore Remøy for hjelp med oversettelse av teksten til norsk. Artikkelen er også et forskingsresultat i prosjektet Strafferettssystemets funksjonalitet som er finansiert av Bergens forskningsstiftelse.

2. Linda Gröning, professor i rettsvitenskap ved Det juridiske fakultet, Universitetet i Bergen. Hun er Juris Dr ved Det juridiske fakultetet i Lund, Sverige, 2008, med avhandlingen $E U$, staten och rätten att straffa: problem och principer för EU:s straffrättsliga lagstiftning. Siden da har hun publisert en rekke artikler og bøker i feltene strafferett, straffegjennomføringsrett og rettsteori. De seneste årene har hun drevet sin forskning innenfor forskningsprosjektet "Strafferettssystemets funksjonalitet", som hun også er prosjektleder for. E-post: Linda.Groning@jur.uib.no

3. Se Andenæs (2004) s. 288.

4. Se strl. $\S \S 39-39$ b. Jf. strl. $2005 \S \S 62-65$.

5. Se strl. §§ 44-46. Jf. strl. $2005 \S 20$.

6. For en utvikling av dette standpunktet, se punkt $12 \mathrm{i}$ vedlegg til NOU 2014:10.

7. Det er imidlertid ikke alltid at dette presiseres og strafferettens ansvarsvilkår omtales vanligvis som straffbarhetsvilkår, se f.eks. Ot.prp. nr. 90 (2003-2004) s. 194.

8. For en fremstilling av tilregnelighetsvilkåret i et historisk perspektiv, se Gran (2014).

9. Jf. Ot.prp. nr 90 (2003-2004) s. 216.

10. Jf. Ross (1974) s. 290.

11. Jf. Andenæs som skiller mellom skyldsynspunkter, allmennpreventive hensyn og behandlingssynspunkter, Andenæs (1974) s. 161-170.

12. Se Ot.prp. nr 90 (2003-2004) s. 216.

13. Ross (1974) s. 290.

14. Se f.eks. Andenæs (2004) s. 288 og Mæland (2012) s. 203. Jf. NOU 1990:5 s. 45-46: «... visse lovbrytere er så psykisk avvikende at de mangler skyldevne og ikke bør gjøres strafferettslig ansvarlig for sine handlinger. I første rekke bør disse fritas fra straff på etisk grunnlag». 
15. Se f.eks. Andenæs (1974) s. 163.

16. Se Ot.prp. nr. 90 (2003-2004) kap. 6 om betydningen av straffens ulike preventive formål.

17. Se Andenæs (1974) s. 163-164, Jf. Bentham (1970), kap. XIII p. 9 og Hart (1968) s. 19.

18. Se Andenæs (2004) s. 292.

19. Se f.eks. SOU 2012:17 s. 540.

20. Om dette argumentet, se f.eks. Waaben (1997) s. 14

21. Se f.eks. Mæland (2012) s. 205. Se også NOU 1983:57 kap. 2.1

22. Se Brottsbalken 30:6. Se punkt 12 i vedlegg til NOU 2014:10 for en nærmere forklaring av denne modellen.

23. Se Jacobsen (2004) s. 394-438. Se også Paternoster (2010) s. 765-824.

24. Jf. Andenæs (1974) s. 164.

25. Jf. Ross (1974) s. 280-284.

26. Se i avsnitt 4 om betingelser for ansvarskapasitet.

27. Straffeloven av 1902 var imidlertid inspirert av teorier om en samfunnsvernsorientert strafferett, men uten å forlate den handlings- og skyldfokuserte modellen. Se videre Jacobsen (2014) s. 44-85.

28. Forvaringsstraffen representerer i dette henseende et brudd med tenkningen som strafferetten ellers bygger på, ettersom den motiveres av samfunnsvern men likevel formelt er straff.

29. For noe ulike modeller, se f.eks. Andenæs (2004) s. 101, Mæland (2012) s. 83, og Eskeland (2013) s. 70-71.

30. Ot.prp. nr. 90 (2003-2004) s. 194.

31. Se Jacobsen (2012a) s. 5-25, Frøberg \& Torgersen (2012) s. 184-205, Jacobsen (2012b) s. 329-343, Frøberg \& Torgersen (2013) s. 80-87 og Jacobsen (2013) s. 89-94.

32. Jf. Ot.prp. $\mathrm{nr} 90$ (2003-2004) s. 66-67.

33. Se strl. $\S \S 42,45$. Jf. Strl. $2005 \S 20$ andre ledd.

34. Jf. Andenæs (2004) s. 290-291 og Ross (1974) s. 292-293 om grensedragningen mellom forsett og tilregnelighet.

35. Se videre i kap. 4 om premissene og forutsetningene for en slik ansvarskapasitet.

36. Se Rt. 2005 s. 104 (39).

37. Se imidlertid SOU 2012:17 s. 706 der det foreslås at tilregnelighetsspørsmålet skal behandles før spørsmålet om forsett.

38. Jf. i Nyhetsbrev fra Den rettsmedisinske kommisjons psykiatriske gruppe, nr. 11, mai 2004: «Det synes i dag ikke riktig å oppfatte psykotiske sykdommer som klart avgrensete tilstander. Det finnes klare variasjoner når det gjelder i hvilken grad psykotiske eller nærpsykotiske symptom påvirker hele den kognitive prosess.» Se også Malt m.fl. (2012) s. 16-17 og Kringlen (2011) s. 43.

39. En annen sak er hvordan den strafferettslige ansvarskapasiteten forstås, og hvilken grad av symptombelastning og funksjonssvikt som må foreligge hos gjerningspersonen på handlingstidspunktet. Jf. f.eks. i NOU 1990:5 s. 38 der psykose som rettslig kriterium for utilregnelighet anses å forutsette at «evnen til realistisk vurdering av ens forhold til omverdenen i vesentlig grad er opphevet».

40. Jf. Andenæs (1974) s. 167. Se også strl. § 56 c, jf. strl. 2005 § 78 c.

41. Jf. f.eks. diskusjonen rundt skadefølgeprinsippet i Ot.prp. nr 90 (2003-2004) kap. 7. 
42. Strafferettens paradigmatiske utgangspunkt er at bare individer kan være straffansvarlige. Men gjeldende straffelov ( $\S 48 \mathrm{a}$ og $48 \mathrm{~b}$ ) tillater samtidig at foretak kan være straffansvarlige, selv om foretak ikke har ansvarsevne i egentlig mening, og det er ganske åpenbart at de ikke heller kan anses å oppfylle strafferettens tilregnelighetsvilkår. På denne måten står straffansvar for foretak i kontrast til den handlings- og skyldorienterte modellens premisser. Se Jacobsen (2009) s. 43-75, men se også Høivik (2012).

43. Se f.eks. Mæland (2012) s. 203, der tilregnelighetsvilkåret koples til en premiss om fri vilje.

44. Se nærmere nedenfor i avsnitt 7 om slike kriterier.

45. Jf. Morse (2011) s. 892-896 som inntar en slik posisjon.

46. Om virkelighetens intersubjektivitet, se Parnas (2008), 170/46 s. 3743-3744.

47. Se videre om signaloverføring og strukturer i hjernen, Malt m.fl. (2012) kap. 4.

48. Døvhet og blindhet kan likevel i visse tilfeller gi opphav til persepsjonsforstyrrelser, se Kringlen (2011) s. 91-92.

49. Se Kringlen (2011) s. 91-96 om ulike tilstander som kan ha betydning for denne evnen.

50. Denne evnen har innen nevrovitenskapen blitt koplet til de såkalte eksekutive funksjonene, se f.eks. Diamond (2013) s. 135-168.

51. Jf. Hagerup (1911) s. 279, 286-287. Jf. også Andenæs som peker på at motivasjonsprosessen er forstyrret ved utilregnelighet, Andenæs (1974) s. 161.

52. Hagerup har her betont at tilregnelighet må forstås som summen av ulike mentale egenskaper, se Hagerup (1911) s. 279.

53. Se videre f.eks. Diamond (2013), Se også Hirstein \& Sifferd (2011) s. 156-171 for en fremstilling av de eksekutive funksjonenes relevans i strafferetten.

54. Jf. f.eks. Andenæs (2004) s. 288.

55. Den som anses som utilregnelig i strafferetten kan også fortsatt anses å ha en viss sivilrettslig ansvarskapasitet. Se Rosenqvist (2009) kap. 13 for en oversikt av situasjonen i norsk rett.

56. Jf. Eastman (1992) s. 162.

57. Avgrensningen til de mest inngripende tilstandene gjelder uansett om utilregneligheten har blitt definert bare ut fra (medisinske) tilstandskriterier eller også med ulike typer av tilleggskriterier (jf. det blandede prinsipp). Se videre nedenfor i avsnitt 7-8.

58. Se f.eks Hauge (2012) s. 455-456, 469.

59. Jf. Eastman (1992) s. 162.

60. Se Kringlen (2011) s. 133-134 om symptomer og funksjonssvikt ved psykose.

61. Se Parnas (2008) s. 3743-3746. Se også NOU 1990:5 s. 38-43 for en forklaring av den juridiske psykosedefinisjonen.

62. Se f.eks. SOU 2012:17 s. 542-543.

63. For en utvikling av argumentet, se f.eks. Morse (2002) s. 1054-1075.

64. Se Malatesti \& McMilliam (2010), for ulike posisjoner i denne diskusjonen. Se Kringlen (2011) s. 155-160, om psykopatibegrepet.

65. Se Vetlesen \& Nortvedt (1996) kap. 2 for en utvikling av dette argumentet.

66. Se f.eks. Morse (2008) s. 205-212 for et slikt standpunkt i relasjon til psykopati.

67. Se om ondskapens problem i f.eks. Svendsen (2002) del III.

68. Knut Waaben har her uttrykt at reglene om utilregnelighet kan betegnes som «et konglomerat af moralske vurderinger og mere praktiske formålsbetraktninger», Waaben (1968) s. 48. 
69. Se Jacobsen (2012c) s. 46-64 for en diskusjon rundt slike reduksjoner i strafferetten.

70. Jf. Andenæs som fremhever det som en umulig oppgave å få frem en allmenngyldig (juridisk) definisjon på tilregnelighet og utilregnelighet, Andenæs (2004) s. 288.

71. For en sammenlikning mellom de nordiske landene, se Kamber (2013) s. 358-368.

72. Se f.eks. Andenæs (2004) s. 288. Se også Syse (2006) s. 141-175. Jf. også for en noe mer differensiert systematikk; Waaben (1997) s. 112-113.

73. Se Andenæs (1974) s. 171-173 om disse reglene.

74. Se SOU 2012:17 s. 561.

75. Se Syse (2006) s. 14, som innordner denne formen av «ikke-styrt helhetsvurdering» som en underkategori i et blandet prinsipp.

76. Se f.eks. Boucht (2012) s. 527-528 og Hauge (2012) s. 465.

77. Psykose kan her beskrives som et alvorlighetskriterium, som kan relatere til flere ulike typer lidelser. Se Malt m.fl. (2012) s. 16-17.

78. Jf. ICD 10: Psykiske lidelser og atferdsforstyrrelser: kliniske beskrivelser og diagnostiske riktlinjer, særlig kap. F 20.

79. Se Parnas (2008) s. 3743, Jf også Lindhardt (2012) s. 563.

80. Se NOU 1990:5 s. 38.

81. Termen «psykotisk» erstattet i dette henseende den tidligere og mer allmennspråklige termen «sinnssyk», se NOU 1990:5 s. 38. Se også Rosenqvist (2012) s. 844, der hun gir uttrykk for at innføringen av termen psykotisk kanskje innebar en forverring.

82. Se NOU 1974:17 s. 149 og NOU 1990:5 pkt. 2.4.

83. For en slik diskusjon, se Moore (2014).

84. Se strl. $\S 39-39$ b. Jf. strl. $2005 \S \S 62-65$.

85. Diskusjonen om beviskravet utelates fra denne fremstillingen, se videre Rt. 1979 s. 143, Rt. 1990 s. 586 og Rt. 2003 s. 23.

86. Se f.eks. SOU 2012:17 kap. 13.2 for en diskusjon rundt dette.

87. Se f.eks. Andenæs (2004) s. 309.

88. Se Løvlie (2012) s. 163-170. En særskilt problematikk i dette henseende er distinksjonen mellom det å ha en «psykosesykdom» og det å være psykotisk. Psykose kan i dag behandles, slik at den som lider av psykosesykdom ikke har en kronisk psykotisk tilstand, men der friskhetsgraden kan variere over perioder. En person kan således være psykotisk på handlingstidpunktet og senere bli bedre. Se Rosenqvist (2012) s. 843.

89. Se Eastman (1992) for en diskusjon om betydningen av psykiatriens ulike modeller.

90. Se om mandatutforming i Nyhetsbrev nr 17 fra den Rettsmedisinske kommisjons psykiatriske gruppe, mars 2007 og Skriv fra Riksadvokaten, 01.03.2007. Se også Røstad (1968) s. 156

91. Jf. Ross (1974) s. 304.

92. Se f.eks. Rosenquist (2009) s. 61.

93. Denne problematikken har også blitt påpekt av Andenæs, se Andenæs (1996) s. 106-107.

94. Muligheten for at personer som var utilregnelige på handlingstidpunktet ikke lengre har behandlingsbehov ved domstidspunktet, eller under gjennomføringen av en særreaksjon finnes allerede innebygget i systemet. Denne muligheten aktualiserer også spørsmålet om de rettspsykiatriske institusjonenes rolle i spørsmålet om å garantere samfunnstrygghet. Se Gröning (2013) s. 153-165. 
95. Se strpl. $§ 459$ og strgjfl. $\S 13$.

96. Se Ministerkomiteens rekommandasjon $\operatorname{Rec}(2006) 2$ til medlemsstatene om de europeiske fengselsreglene p. 12.1-2.

97. Se Hartvig \& Østberg (2004) s. 2091-2093 og Langeveld \& Melhus (2004) s. 2094-2097.

98. For en fremstilling i dette henseendet, se Berger (2012) s. 117-139.

99. Jf. SOU 2012:17 s. 541.

100. Se Ot.prp. nr. 90 (2003-2004). s. 80-81.

101. Se f.eks. retningslinjer till strgjfl. pkt. 3.3.

102. Se Ryssdal m.fl. (2008) s. 6-35 for en problematisering av «den allmenne rettsfølelsen». Se også Ryberg (2006).

103. En annen sak er at det kan argumenteres for at straffeprosessen, og da særlig domstolsbehandlingen, i større grad kan gi plass for offerets behov av å få erkjennelse og oppgjør, uten at dette skal innvirke på om og hvordan gjerningspersonen straffes. Se f.eks. Leer-Salvesen (2009) s. 87-114.

104. Se videre Nygaard (2007) s. 435-440.

105. Se Strandbakken (2003) s. 232-233 om de ulike bevistersklenes betydning.

\section{Litteraturliste}

Andenæs, Johs., Straffen som problem, 2. reviderte opplag, (Exil 1996)

Andenæs, Johs., «Grunnlaget for utilregnelighetsreglene», vedlegg NOU 1974:17 s. 161-170

Andenæs, Johs., Alminnelig strafferett, 5. utg. ved Magnus Matningsdal og Georg Fredrik Rieber-Mohn, (Universitetsforlaget 2004)

Bentham, Jeremy, An Introduction to the Principles of Morals and Legislation, Burns and Hart, red. (Hafner Pub. Co. 1948)

Berger, Benjamin L., «Mental Disorder and the Instability of Blame in Criminal Law», Rethinking Criminal Law Theory, Tanguay-Renaud, François og Stribopoulous, James, red., (Hart Pub. 2012)

Boucht, Johan, «Om strafferettslig tilregnelighet i norsk rett - med noen synspunkter fra et nordisk perspektiv», Lov og Rett (2012) s. 515-532

Diamond, Adele, «Executive functions», Annual Review of Psychology (2013) s. 135-168

Eastman, Nigel, «Psychiatric, psychological and legal models of man», International Journal of Law and Psychiatry (1992) s. 162

Eskeland, Ståle, Strafferett, 3. utg., (Cappelen Damm Akademisk 2013)

Frøberg, Thomas \& Torgersen, Runar, «Noen kommentarer til Jørn RT Jacobsens artikkel «Eit grunnriss av ei strafferettsleg ansvarslære»"), Tidsskrift for strafferett (2012) s. 184-205

Frøberg, Thomas \& Torgersen, Runar, «Noen ytterligere kommentarer til Jørn RT Jacobsens utkast til en ny ansvarslære», Tidsskrift for strafferett (2013) s. 80-87

Gran, Bernt, Hundreår med hodebry: utilregnelighetens historie, (Cappelen Damm 2014)

Gröning, Linda, «Sjuk, frisk och farlig: tankar om straffrättens reaktionssystem i gränssnittet mellan straff, vård och samhällsskydd», i Undring og erkjennelse. Festskrift til Jan Fridthjof Bernt 70 år, (Fagbokforlaget 2013) s. 153-165

Hagerup, Francis, Strafferettens almindelige del, (Aschehoug \& co 1911)

Hart, Herbert Lionel Adolphus, Punishment and Responsibility: Essays in the philosophy of Law, (Oxford University Press 1968) 
Hartvig, Pål \& Østberg, Bjørn, «Psykisk lidelse og avvik blant norske fengselsinnsatte», Tidsskrift for Den norske legeforening (2004) s. 2091-2093

Hauge, Steinar M., «Rettspsykiatri i støpeskjeen», Tidsskrift for strafferett (2012) s. 455-469

Hirstein, William \& Sifferd, Katrina, "The legal self: Executive processes and legal theory», Consciousness and Cognition (2011) s. 156-171

Høivik, Knut, Foretaksstraff: En analyse av ansvarskonstruksjonen og dens historiske, rettspolitiske og moralske forutsetninger, (Cappelen Damm Akademisk 2012)

Jacobsen, Jørn RT, «Diskusjonen om allmennprevensjonen sin faktiske verknad», Tidsskrift for Strafferett $n r .4$ (2004) s. 394-438

Jacobsen, Jørn RT, «Fiksjon utan moral eller konstruksjon utan verdi? Om det ideologiske grunnlaget for straffansvar for juridiske personar», Tidsskrift for strafferett (2009) s. 43-75

Jacobsen, Jørn RT, «Eit grunnriss av ei strafferettsleg ansvarslære», Tidsskrift for strafferett (2012) s. 184-205

Jacobsen, Jørn RT, «Rett/sleg forståing: Svar til Thomas Frøberg og Runar Torgersen», Tidsskrift for strafferett (2012) s. 329-343

Jacobsen, Jørn RT, «Concepts of Criminal Law and Representative Reductions», Nordisk Tidsskrift for Kriminalvidenskab (2012) s. 46-64

Jacobsen, Jørn RT, «Sluttreplikk om ei strafferettsleg ansvarslære», Tidsskrift for strafferett (2013) s. 89-94

Jacobsen, Jørn RT, ««i selve Dybderne af den mennesklige Bevidsthed om Ret og moral»Straffelova av 1902 og den tyske skulestriden», Geir Heivoll og Sverre Flaatten, red, «Straff, lov, historie» Historiske perspektiver på straffeloven av 1902 (Akademisk Publisering 2014)

Kamber, Simon Engell, «Psykisk syge lovovertrædere i et komparativt lys», Nordisk Tidsskrift for Kriminalvidenskab (2012) s. 46-64

Kringlen, Einar, Psykiatri, 10. utg., (Gyldendal Akademisk 2011)

Langeveld, Hans \& Melhus, Henning, «Blir psykiske lidelser i fengsel fanget opp av helsetjenesten?», Tidsskrift for Den norske legeforening (2004) s. 2094-2097

Leer-Salvesen, Paul, Forsoning etter krenkelser, (Fagbokforlaget 2009)

Lindhardt, Anne, «Der er særlige etiske konsekvenser af psykosediagnosen», Ugeskrift for Lager 174/9 (2012) s. 563-565

Løvlie, Anders, «Strafferettslig psykose - bevistema og beviskrav», Kritisk Juss (2012) s. 158180.

Malt, Ulrik Fredrik m.fl (red.), Laerebok i psykiatri, 3. utg., (Gyldendal Akademisk 2012)

Malatesti, Luca \& McMillan John (red.), Responsibility and Psychopathy: interfacing law, psychiatry and philosophy, (Oxford University Press 2010)

Moore, Michael S., «Responsible Choices, desert-based legal institutions, and the challenges of contemporary neuroscience», Social Philosophy and Policy (2012) s. 245-279

Moore, Michael S., «The Quest for a Responsible Responsibility Test: Norwegian Insanity Law After Breivik», Journal of Criminal Law and Philosophy (2014)

Morse, Stephen, «Uncontrollable Urges and Irrational People», Virginia Law Review (2002) s. 1054-1075

Morse, Stephen, «Mental Disorder and Criminal Law», The Journal of Criminal Law and Criminology Vol. 101, (2011) s. 885-939

Morse, Stephen J., «Psychopathy and Criminal Responsibility», Neuroethics (2008) s. 205-212 
Mæland, Henry John, Norsk alminnelig strafferett, (Justian 2012)

Nygaard, Nils, Skade og ansvar, (Universitetsforlaget 2007)

Parnas, Josef, «Begrebet psykose», Ugeskrift for Laeger (2008, 170/46 s. 3743-3744

Paternoster, Raymond, «How much do we really know about criminal deterrence», The Journal of Criminal Law and Criminology 100 (2010) s. 765-824

Rosenqvist, Randi, Rettspsykiatri - en introduksjon, (Universitetsforlaget 2009)

Rosenqvist, Randi, «Utilregnelighetsregelen - moden for revisjon?», Tidsskrift for den Norske Legeforening (2012) s. 843-844

Ross, Alf, Forbrydelse og straf: analytiske og reformatoriske bidrag til kriminalrettens almindelige del, (Nyt Nordisk Forlag 1974)

Ryberg, Jesper, Retsfølelsen: en bog om straf og etik, (Roskilde Universitetsforlag 2006)

Ryssdal, Anders, «Advokatforeningens årstale 2007: Den allmenne rettsfølelse - veiviser eller rettleder i strafferetten?», Kritisk Juss (2008) s. 6-35

Strandbakken, Asbjørn, «Simpson i Strasbourg», Lov og Rett (2003) s. 231-248

Svendsen, Lars Fredrik Händler, Ondskapens filosofi, (Universitetsforlaget 2002)

Syse, Aslak, «Strafferettslig (u)tilregnelighet: juridiske, moralske og faglige dilemmaer», Tidsskrift for strafferett (2006) s. 141-175

Vetlesen, Arne Johan \& Nordtvedt, Per, Følelser og moral, (Ad Notam Gyldendal 1996)

Waaben, Knud, Utilregnelighed og sarbehandling, (Københavns universitet 1968)

Waaben, Knud, Retspsykiatri og strafferet i historiens lys, (Janssen-Cilag 1997) 